\title{
Contributions to the Interpretation of Mass Spectra of the TEOS Methoxy-Transesters. Linked Scans, Accurate Mass Measurements and M+1, M+2 Isotopic Effects
}

\author{
VIRGIL BADESCU* \\ National Research \& Development Institute for Chemistry \& Petrochemistry - ICECHIM, Analytical Department, 202 Splaiul \\ Independentei, 060021, Bucharest, Romania
}

\begin{abstract}
The aim of this article is the study of the fragmentation reactions of the methoxy-transesters of tetraethoxysilane (TEOS), with structural formula $\left(\mathrm{CH}_{3} \mathrm{O}\right)_{x}\left(\mathrm{C}_{2} \mathrm{H}_{5} \mathrm{O}\right)_{y} \mathrm{Si}$, initiated by electronic impact in the ionization chamber of a double focusing mass spectrometer. The initiation centers of fragmentation reactions for the neutral and ionized TEOS methoxy-transesters were established by quantum calculations of net atomic charges. The ions of the mass spectra of the TEOS methoxytransesters were obtained experimentally by the $B / E$ and $B / E(1-E)^{1 / 2}$ linked scans. Thus, there can be written the fragmentation pathways for the primary events by B/E linked scan (cleavage of methoxy and ethoxy groups) and eliminations of neutral molecules (acetaldehyde, ethylene, formaldehyde, molecular hydrogen) by $B / E(1-E)^{1 / 2}$ linked scan. Accurate mass measurements at high resolution (5000), double bond equivalent (DBE) for the molecular ions and fragmentation ions of the TEOS methoxytransesters and $M+1, M+2$ isotopic effects were used to confirm their identification. The reaction pathways and accurate mass in mass spectrum of dimethoxydiethoxysilane (TR2M) are detailed.
\end{abstract}

Keywords: TEOS methoxy-transesters, mass spectra, linked scans, accurate masses, isotopic effects

\section{Introduction}

The first purpose of the author thesis [1] was the separation and identification of molecular species obtained in the sol-gel process by gas chromatography coupled with mass spectrometry (GC-MS). An important reference for the application of GC-MS in the sol-gel process was Wheeler's thesis [2].

The basic factors that influence the sol-gel process have been studied systematically by GC-MS: type of precursor alkoxide, the solvent nature, the water quantity used in hydrolysis, the reactant mixing order and the catalyst type. The results were published between 1994 and 2007 [3-9].

The second purpose of the author thesis [1] was the development of a procedure for the interpretation of mass spectra of some silicon alkoxides and their transesters and oligomers obtained by the sol-gel process.

We mention a few references regarding the interpretation of mass spectra: A general procedure for the interpretation of mass spectra was presented in reference [10]. The relationship between the chemical structure of the molecules and their mass spectra has been highlighted by Lafferty [11]; according to his theory the relative intensity of fragmentation ions is determined by the stability of the reaction products and of the bond strength. A complementary theory has been developed by Djerassi [12]; according to his theory, the charge and radical localization after ionization contributes to establish the initiation centers of the fragmentation reactions.

The author's procedure for the interpretation of mass spectra of silicon alkoxides $[1,13]$ was applied for TEOS [13,14,16], TEOS dimer [15] and TEOS cyclic tetramer [17].

*email:virgil_badescu@yahoo.com 


\section{Methods and working conditions}

Table 1. GC-MS method and optimization parameters

\begin{tabular}{|c|c|}
\hline \multicolumn{2}{|c|}{ Working conditions for the HP 5890 gas chromatograph } \\
\hline Injection mode & Splitting injection 1:70 \\
\hline Injection port temperature & $250^{\circ} \mathrm{C}$ \\
\hline Injection volume & $0.1-0.3 \mu 1$ \\
\hline GC-MS interface temperature & $280^{\circ} \mathrm{C}$ \\
\hline $\begin{array}{l}\text { Column: } \\
\text { - stationary phase } \\
\text { - size } \\
\text { - temperature program } \\
\text { - carrier gas }\end{array}$ & $\begin{array}{l}\text { A fused silica high-performance capillary column Silicone oil OV-1 } \\
25 \mathrm{~m} \times 0.25 \mathrm{~mm} \times 0.1 \mu \mathrm{m} \text { film thickness of stationary phase with } 70,000 \\
\text { theoretical plates } \\
40^{\circ} \mathrm{C}(3 \mathrm{~min} .), 15^{\circ} \mathrm{C} / \mathrm{min} \text {, to } 220^{\circ} \mathrm{C}(5 \mathrm{~min}) \\
\text { Helium flow rate } 1 \mathrm{ml} / \mathrm{min} .\end{array}$ \\
\hline \multicolumn{2}{|c|}{ Working conditions for 70-SE, VG Analytical double focusing mass spectrometer } \\
\hline Acquisition mode & SCN \\
\hline Ion source temperature & $180^{\circ} \mathrm{C}$ \\
\hline Electron energy & $70 \mathrm{eV}$ \\
\hline Response time & $0.03 \mathrm{~ms}$ \\
\hline Accelerating voltage & $8 \mathrm{kV}$ \\
\hline Electronic amplifier & 250 \\
\hline Daughter ions of a preset ion & $\mathrm{B} / \mathrm{E}=\mathrm{constant}$ \\
\hline The ions which lose small molecules & $(\mathrm{B} / \mathrm{E})(1-\mathrm{E})^{1 / 2}=\mathrm{constant}$ \\
\hline
\end{tabular}

For the interpretation of the TEOS mass spectrum, the linked scans were used to study the metastable ions obtained in the first region without field (FFR1):

The B/E linked scan: This method of scanning allows obtaining daughter ions $\mathrm{m}_{2}{ }^{+}$from a preset precursor ion $\mathrm{m}_{1}{ }^{+}$. The condition for obtaining the daughter ion is $\mathrm{B} / \mathrm{E}=$ constant, where $\mathrm{B}$ is the magnetic field, and $\mathrm{E}$ is the electric field applied in the magnetic and electric sectors of the mass spectrometer.

The (B/E)(1-E) $)^{1 / 2}$ linked scan: It is used to obtain the ions which lose small molecules with a preset mass (e.g. ethylene, acetaldehyde, formaldehyde, $\mathrm{H}_{2}$, etc.).

\section{Results and discussions}

\subsection{The separation and identification of the TEOS methoxy-transesters by GS-MS}

The attribution of the structures for methoxytriethoxysilane (TR1M), dimethoxydiethoxysilane (TR2M), trimethoxyethoxysilane (TR3M) and tetramethoxysilane (TR4M, TMOS) was argued by the gas-chromatographic retention times (Figure 1b) and by direct comparison of the EI mass spectra shown in Figure 2a-e [1-3].

The methoxy-transesters of tetraethoxysilane (TEOS), with structural formula $\left(\mathrm{CH}_{3} \mathrm{O}\right)_{\mathrm{x}}\left(\mathrm{C}_{2} \mathrm{H}_{5} \mathrm{O}\right)_{\mathrm{y}} \mathrm{Si}$ are obtained in the sol-gel process [1-3] by reactions (1)-(4).

$$
\begin{aligned}
& \left(\mathrm{C}_{2} \mathrm{H}_{5} \mathrm{O}\right)_{4} \mathrm{Si}+\mathrm{CH}_{3} \mathrm{OH} \leftrightarrow\left(\mathrm{CH}_{3} \mathrm{O}\right) \mathrm{Si}\left(\mathrm{OC}_{2} \mathrm{H}_{5}\right)_{3}+\mathrm{C}_{2} \mathrm{H}_{5} \mathrm{OH} \\
& \left(\mathrm{CH}_{3} \mathrm{O}\right) \mathrm{Si}\left(\mathrm{OC}_{2} \mathrm{H}_{5}\right)_{3}+\mathrm{CH}_{3} \mathrm{OH} \leftrightarrow\left(\mathrm{CH}_{3} \mathrm{O}\right)_{2} \mathrm{Si}\left(\mathrm{OC}_{2} \mathrm{H}_{5}\right)_{2}+\mathrm{C}_{2} \mathrm{H}_{5} \mathrm{OH} \\
& \left(\mathrm{CH}_{3} \mathrm{O}\right)_{2} \mathrm{Si}\left(\mathrm{OC}_{2} \mathrm{H}_{5}\right)_{2}+\mathrm{CH}_{3} \mathrm{OH} \leftrightarrow\left(\mathrm{CH}_{3} \mathrm{O}\right)_{3} \mathrm{Si}\left(\mathrm{OC}_{2} \mathrm{H}_{5}\right)+\mathrm{C}_{2} \mathrm{H}_{5} \mathrm{OH} \\
& \left(\mathrm{CH}_{3} \mathrm{O}\right)_{3} \mathrm{Si}\left(\mathrm{OC}_{2} \mathrm{H}_{5}\right)+\mathrm{CH}_{3} \mathrm{OH} \leftrightarrow\left(\mathrm{CH}_{3} \mathrm{O}\right)_{4} \mathrm{Si}+\mathrm{C}_{2} \mathrm{H}_{5} \mathrm{OH}
\end{aligned}
$$

The transesterification reactions of TEOS, in nonparental solvents $\left(\mathrm{CH}_{3} \mathrm{OH}\right)$ advance to the total replacement of ethoxy group by methoxy groups.

The chromatograms for TEOS monomers in reaction mixtures with parental and nonparental solvents, are shown in Figure 1 [1,3].

The mass spectra of the TEOS methoxy-transesters are like to that of TEOS but contain molecular and fragmentation ions with 14 units less which correspond to the difference between the mass of the methyl and ethyl groups (Figure 2a-e). 

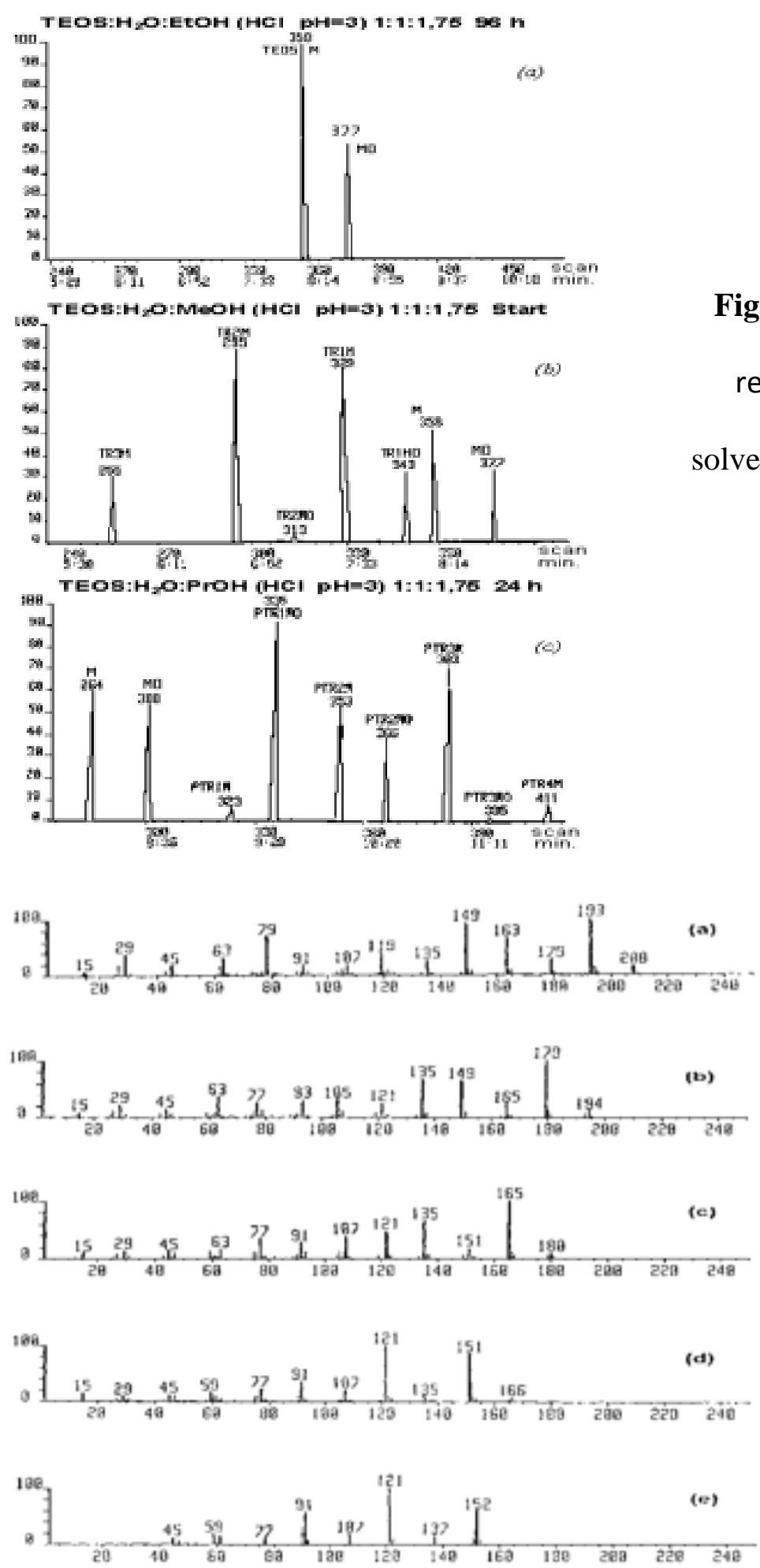

Figure 1. The chromatograms for TEOS monomers in the reaction mixture: (a) parental solvent

(b) lower nonparental solvent $(\mathrm{MeOH})$, and (c) higher nonparental solvent $(\mathrm{n}-\mathrm{PrOH})$
Figure 2.a-e. The EI mass spectra of the TEOS methoxy-transesters: (a) TEOS, (b) TR1M, (c) TR2M, (d) TR3M, (e) TR4M

\subsection{Contributions to the interpretation of mass spectra of the TEOS methoxy-transesters}

In this work, we present a study of the reactivity of these molecular species obtained in the sol-gel process by interpreting their mass spectra.

For the easier viewing of exposure, the mass spectra of the TEOS methoxy-transesters (TR1MTR4M) are given in Tables 1-4 as table-mass-intensity pairs; the intensity is expressed as a percentage relative to the basic peak normalized to $\mathrm{I}=100$. 
Table 2. The mass spectrum of methoxytriethoxysilane (TR1M) at resolution $\mathrm{R}=1000$

\begin{tabular}{|c|c|c|c|c|c|c|c|c|c|}
\hline Mass & $\begin{array}{c}\text { Intensity } \\
\%\end{array}$ & Mass & $\begin{array}{c}\text { Intensity } \\
\%\end{array}$ & Mass & $\begin{array}{c}\text { Intensity } \\
\%\end{array}$ & Mass & $\begin{array}{c}\text { Intensity } \\
\%\end{array}$ & $\begin{array}{c}\text { Mass } \\
\text { Intensity } \\
\%\end{array}$ \\
\hline 15 & 7.3 & 90 & 2.8 & 119 & 8.1 & 139 & 0.7 & 167 & 1.7 \\
\hline 29 & 21.0 & 91 & 6.7 & 120 & 0.8 & 147 & 0.8 & 177 & 1.0 \\
\hline 31 & 3.2 & 93 & 30.2 & 121 & 24.6 & $\mathbf{1 4 9}$ & $\mathbf{6 3 . 9}$ & $\mathbf{1 7 9}$ & $\mathbf{1 0 0 . 0}$ \\
\hline 45 & 12.9 & 94 & 2.1 & 122 & 2.2 & 150 & 7.1 & 180 & 11.3 \\
\hline 59 & 6.4 & 95 & 1.5 & 123 & 2.3 & 152 & 0.8 & 181 & 4.8 \\
\hline 63 & 36.2 & 105 & 30.0 & 133 & 2.5 & 153 & 0.8 & 182 & 0.3 \\
\hline 77 & 24.6 & 106 & 3.0 & 135 & 67.5 & $\mathbf{1 6 3}$ & $\mathbf{2 . 2}$ & $\mathbf{1 9 3}$ & $\mathbf{5 . 5}$ \\
\hline 78 & 2.0 & 107 & 10.2 & 136 & 6.3 & 164 & 0.4 & $\mathbf{1 9 4}$ & $\mathbf{1 0 . 7} \boldsymbol{M}^{+}$ \\
\hline 79 & 12.5 & 108 & 0.8 & 137 & 8.0 & $\mathbf{1 6 5}$ & $\mathbf{2 2 . 1}$ & 195 & 1.6 \\
\hline 89 & 3.6 & $\mathbf{1 1 8}$ & $\mathbf{1 . 0}$ & 138 & 0.6 & 166 & 2.9 & 196 & 0,5 \\
\hline
\end{tabular}

Table 3. The mass spectrum of dimethoxydiethoxysilane (TR2M) at resolution $\mathrm{R}=1000$

\begin{tabular}{|c|c|c|c|c|c|c|c|c|c|}
\hline Mass & $\begin{array}{c}\text { Intensity } \\
\%\end{array}$ & Mass & $\begin{array}{c}\text { Intensity } \\
\%\end{array}$ & Mass & $\begin{array}{c}\text { Intensity } \\
\%\end{array}$ & Mass & $\begin{array}{c}\text { Intensity } \\
\%\end{array}$ & Mass & $\begin{array}{c}\text { Intensity } \\
\%\end{array}$ \\
\hline 15 & 8.2 & 75 & 10.2 & 94 & 0.7 & 122 & 4.0 & 152 & 2.3 \\
\hline 29 & 11.3 & 76 & 8.7 & 104 & 2.7 & 123 & 2.7 & 153 & 1.7 \\
\hline 31 & 3.0 & 77 & 33.0 & 105 & 11.2 & 133 & 1.5 & 165 & 100.0 \\
\hline 45 & 10.4 & 78 & 2.5 & 106 & 1.5 & 135 & 64.3 & 166 & 10.0 \\
\hline 46 & 1.8 & 79 & 3.1 & 107 & 37.1 & 136 & 6.1 & 167 & 4.4 \\
\hline 59 & 10.3 & 90 & 4.5 & 108 & 2.7 & 137 & 6.0 & 179 & 4.8 \\
\hline 60 & 3.3 & 91 & 25.7 & 109 & 2.2 & 149 & 4.3 & 180 & $7.7 M^{+}$ \\
\hline 63 & 15.0 & 92 & 2.2 & 118 & 0.2 & 150 & 0.5 & 181 & 1.2 \\
\hline 64 & 0.9 & 93 & 10.2 & 121 & 46.6 & 151 & 16.1 & 182 & 0.4 \\
\hline
\end{tabular}

Table 4. The mass spectrum of trimethoxyethoxysilane (TR3M) at resolution $\mathrm{R}=1000$

\begin{tabular}{|c|c|c|c|c|c|c|c|c|c|}
\hline Mass & $\begin{array}{c}\text { Intensity } \\
\%\end{array}$ & Mass & $\begin{array}{c}\text { Intensity } \\
\%\end{array}$ & Mass & $\begin{array}{c}\text { Intensity } \\
\%\end{array}$ & Mass & $\begin{array}{c}\text { Intensity } \\
\%\end{array}$ & Mass & $\begin{array}{c}\text { Intensity } \\
\%\end{array}$ \\
\hline 15 & 12.7 & 61 & 8.8 & 79 & 1.7 & 107 & 18.9 & 138 & 2.5 \\
\hline 29 & 7.4 & 62 & 1.7 & 90 & 7.9 & 108 & 1.5 & 151 & 85.4 \\
\hline 31 & 3.1 & 63 & 4.5 & 91 & 34.6 & 121 & 100.0 & 152 & 8.8 \\
\hline 45 & 9.7 & 64 & 0.4 & 92 & 3.1 & 122 & 8.7 & 153 & 4.4 \\
\hline 47 & 8.9 & 75 & 6.9 & 93 & 3.2 & 123 & 4.7 & 165 & 3.6 \\
\hline 48 & 0.5 & 76 & 7.1 & 104 & 1.5 & 135 & 7.0 & 166 & $5.9 M^{+}$ \\
\hline 59 & 14.2 & 77 & 21.3 & 105 & 3.5 & 136 & 0.8 & 167 & 0.8 \\
\hline 60 & 5.0 & 78 & 1.7 & 106 & 1.3 & 137 & 3.6 & 168 & 0.4 \\
\hline
\end{tabular}

Table 5. The mass spectrum of tetramethoxysilane (TR4M-TMOS) at resolution $\mathrm{R}=1000$.

\begin{tabular}{|c|c|c|c|c|c|c|c|c|c|}
\hline Mass & $\begin{array}{c}\text { Intensity } \\
\%\end{array}$ & Mass & $\begin{array}{c}\text { Intensity } \\
\%\end{array}$ & Mass & $\begin{array}{c}\text { Intensity } \\
\%\end{array}$ & Mass & $\begin{array}{c}\text { Intensity } \\
\%\end{array}$ & $\begin{array}{c}\text { Mass } \\
\text { Intensity }\end{array}$ \\
\hline 15 & 18.9 & 48 & 0.4 & 77 & 9.3 & 107 & 15.4 & $\mathbf{1 3 7}$ & $\mathbf{7 . 2}$ \\
\hline
\end{tabular}




\begin{tabular}{|c|c|c|c|c|c|c|c|c|c|}
\hline 29 & 10.8 & 59 & 16.8 & 78 & 0.8 & 108 & 1.3 & 138 & 0.8 \\
\hline 31 & 6.9 & 60 & 6.6 & $\mathbf{9 0}$ & $\mathbf{3 2 . 3}$ & 109 & 0.8 & $\mathbf{1 5 1}$ & $\mathbf{8 . 9}$ \\
\hline 45 & 12.5 & 61 & 14.9 & 91 & 46.6 & $\mathbf{1 2 1}$ & $\mathbf{1 0 0 . 0}$ & $\mathbf{1 5 2}$ & $\mathbf{5 8 . 2} \boldsymbol{M}^{+.}$ \\
\hline 46 & 2.1 & 62 & 1.9 & 92 & 4.7 & 122 & 9.5 & 153 & 6.1 \\
\hline 47 & 7.0 & 75 & 7.0 & 93 & 2.2 & 123 & 4.6 & 154 & 2.6 \\
\hline
\end{tabular}

\subsection{The ionization process and obtaining molecular ions}

The ionization process for the TR1M-TR4M molecular species takes place according to equation (5) by eliminating a nonparticipant electron of the oxygen atom of a methoxy or ethoxy group.

$$
\equiv \mathbf{S i}-\overline{\mathbf{O}}-\mathbf{R}+\mathbf{e}^{-} \longrightarrow \equiv \mathbf{S i}-\underline{+} \dot{\mathbf{O}}-\mathbf{R}+2 \mathbf{e}^{-}
$$

An argument in favor of this premise is the net atomic charge calculations performed with the MOPAC 7 program for these species before and after ionization compared to the same process for TEOS as the reference system. Figure 3.a-e. shows net atomic charges for (a) tetraethoxysilane (TEOS), (b) - (e) the TEOS methoxy-transesters and their molecular ions obtained in the process of ionization by electron impact at $70 \mathrm{eV}$. Charge centers are located on the oxygen atoms in the ethoxy and methoxy groups [1].

Quantum calculations with the MOPAC 7 program also provided other significant data for the methoxy-transesters of TEOS before and after ionization: dipole moments and ionization potentials (Table 6). In the same table are presented the structural formulas of the discussed molecular species and their molecular ions.
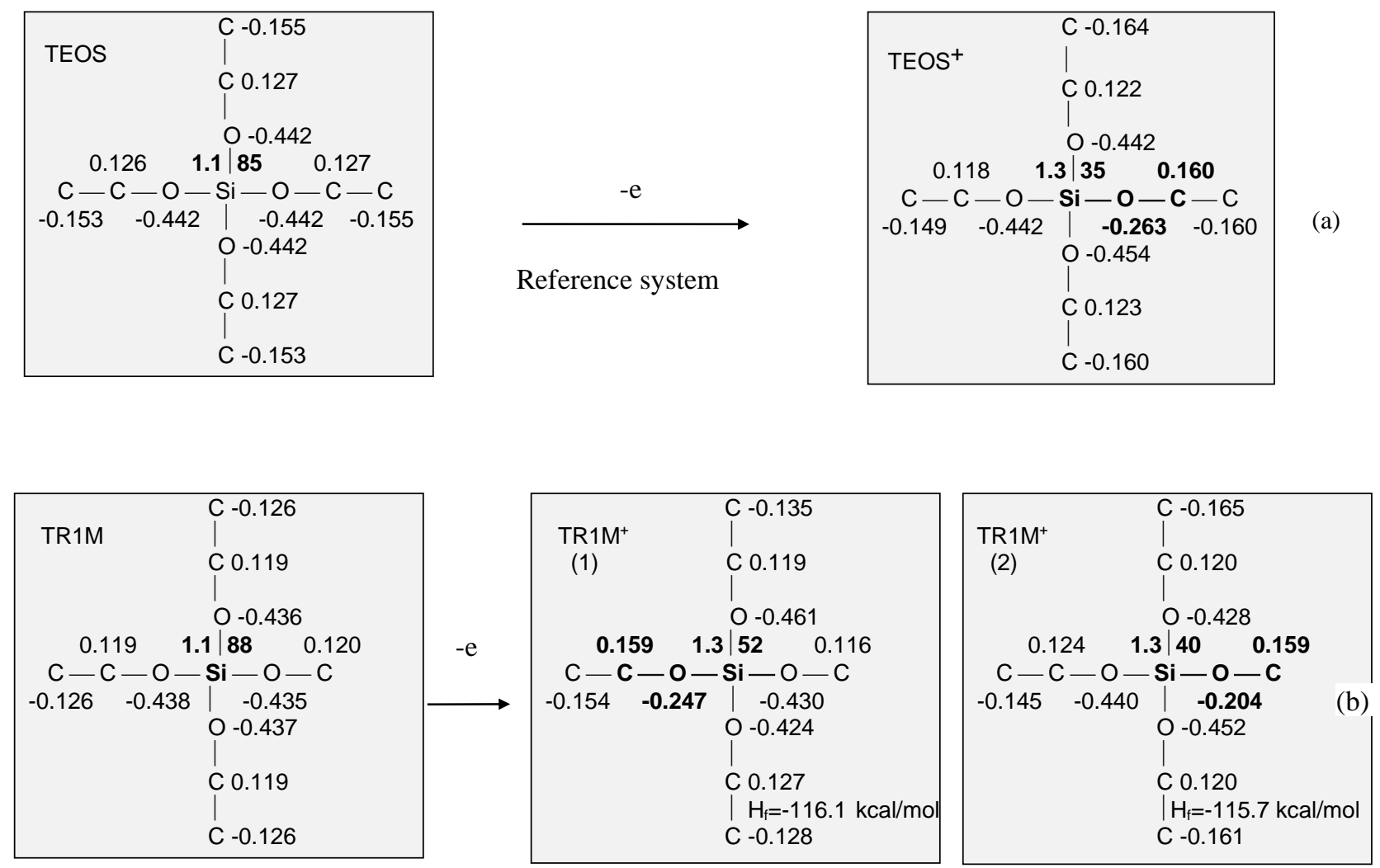


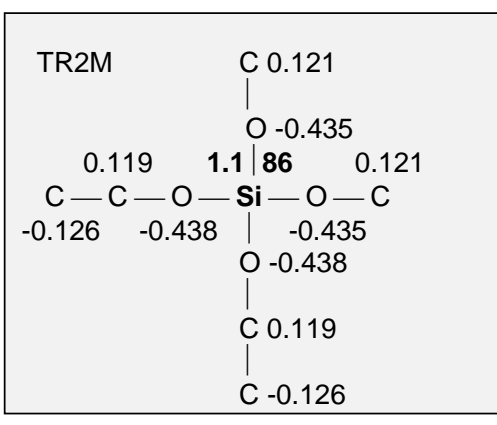

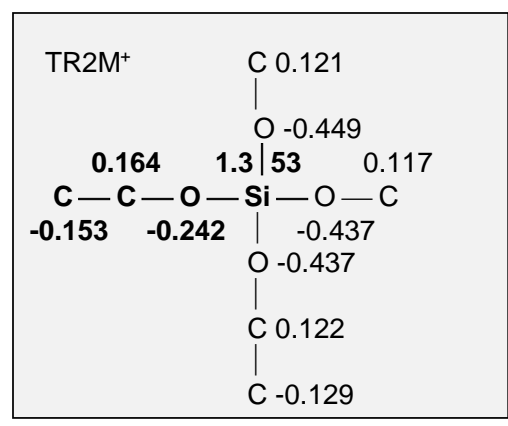

(c)

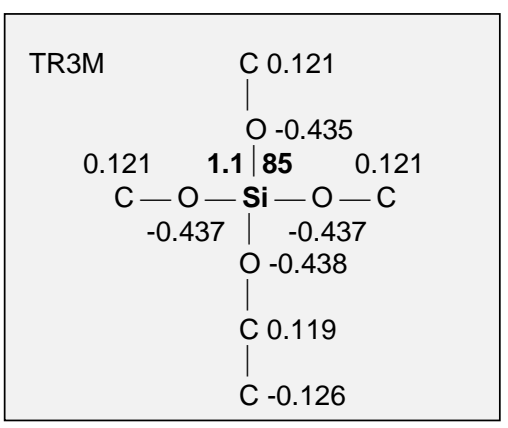

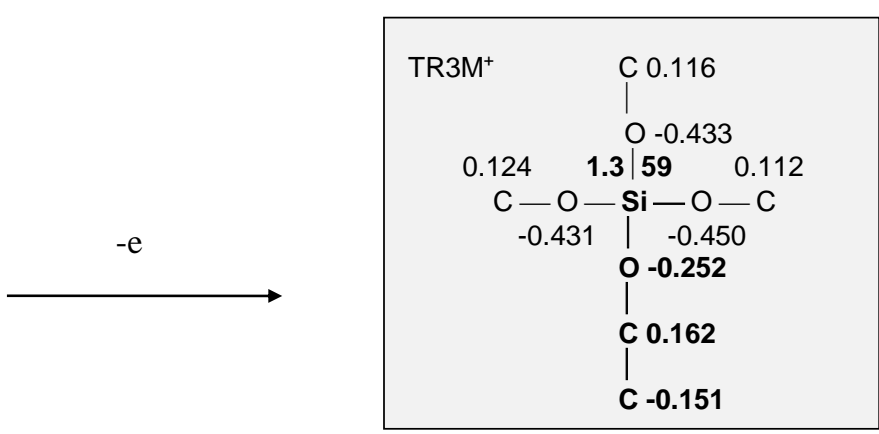

(d)
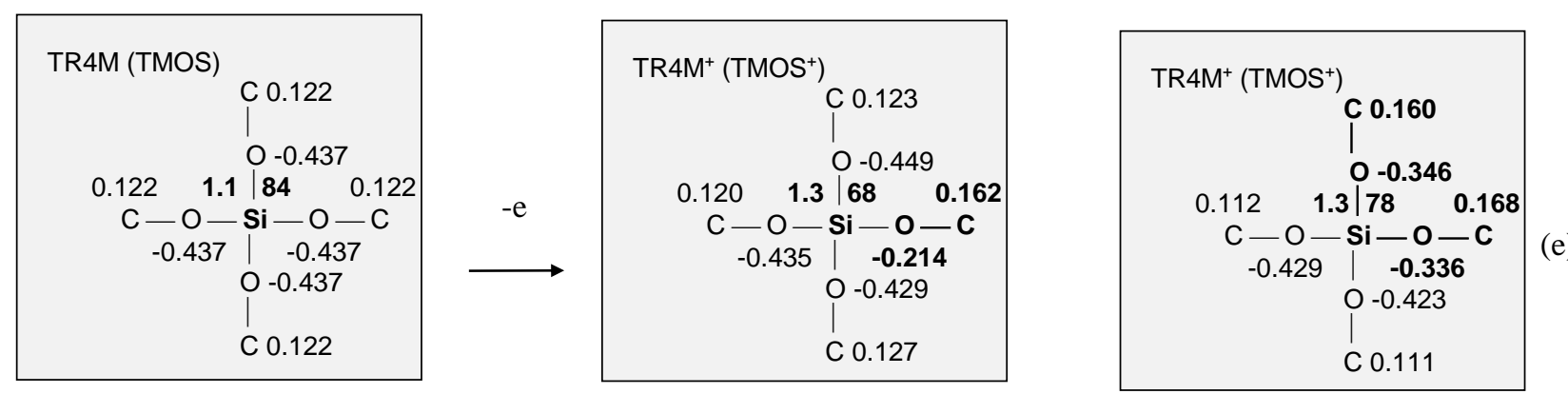

Figure 3.a-e. Net atomic charges by quantum calculations MOPAC 7 (a) tetraethoxysilane (TEOS), (b) - (e) the TEOS methoxy-transesters and their molecular ions]. Charge delocalizations are bold

Table 6. The TEOS methoxy-transesters: The reaction centers in the molecular ions, dipole moments and ionization potentials by quantum calculations with program MOPAC 7

\begin{tabular}{|c|c|c|c|c|c|}
\hline Molecular/ionic species & $\begin{array}{c}\text { Molecular/ } \\
\text { Ionic formula }\end{array}$ & Structural formula & $\begin{array}{l}\text { Molecular/ } \\
\text { Ionic mass }\end{array}$ & $\begin{array}{l}\text { Dipole moment } \\
\text { (Debye) }\end{array}$ & $\begin{array}{c}\text { Ionization potential } \\
(\mathrm{eV})\end{array}$ \\
\hline Tetraethoxysilane & $\mathrm{C}_{8} \mathrm{H}_{20} \mathrm{O}_{4} \mathrm{Si}$ & $\left(\mathrm{C}_{2} \mathrm{H}_{5} \mathrm{O}\right)_{4} \mathrm{Si}$ & 208 & 0.01 & 10.10 \\
\hline Molecular ion & $\mathrm{C}_{8} \mathrm{H}_{20} \mathrm{O}_{4} \mathrm{Si}^{+}$ & $\left(\mathrm{C}_{2} \mathrm{H}_{5} \mathrm{O}\right)_{3} \mathrm{Si}-\stackrel{+}{\underline{0}}-\mathrm{CH}_{2}-\mathrm{CH}_{3}$ & 208 & 4.22 & 15.93 \\
\hline Methoxytriethoxysilane & $\mathrm{C}_{7} \mathrm{H}_{18} \mathrm{O}_{4} \mathrm{Si}$ & $\left(\mathrm{CH}_{3} \mathrm{O}\left(\mathrm{C}_{2} \mathrm{H}_{5} \mathrm{O}\right)_{3} \mathrm{Si}\right.$ & 194 & 0.06 & 10.04 \\
\hline Molecular ion & $\mathrm{C}_{7} \mathrm{H}_{18} \mathrm{O}_{4} \mathrm{Si}^{+}$ & 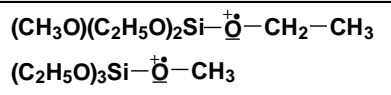 & 194 & 3.93 & 15.86 \\
\hline Dimethoxidiethoxysilane & $\mathrm{C}_{6} \mathrm{H}_{16} \mathrm{O}_{4} \mathrm{Si}$ & $\left(\mathrm{CH}_{3} \mathrm{O}\right)_{2}\left(\mathrm{C}_{2} \mathrm{H}_{5} \mathrm{O}\right)_{2} \mathrm{Si}$ & 180 & 0.06 & 10.06 \\
\hline Molecular ion & $\mathrm{C}_{6} \mathrm{H}_{16} \mathrm{O}_{4} \mathrm{Si}^{+}$ & $\begin{array}{l}\left(\mathrm{CH}_{3} \mathrm{O}\right)_{2}\left(\mathrm{C}_{2} \mathrm{H}_{5} \mathrm{O}\right) \mathrm{Si}-\underline{\mathrm{O}}-\mathrm{CH}_{2}-\mathrm{CH}_{3} \\
\left(\mathrm{CH}_{3} \mathrm{O}\right)\left(\mathrm{C}_{2} \mathrm{H}_{5} \mathrm{O}\right)_{2} \mathrm{Si}-\stackrel{+}{\mathrm{o}}-\mathrm{CH}_{3}\end{array}$ & 180 & 3.20 & 15.84 \\
\hline Trimethoxyethoxysilane & $\mathrm{C}_{5} \mathrm{H}_{14} \mathrm{O}_{4} \mathrm{Si}$ & $\left(\mathrm{CH}_{3} \mathrm{O}\right)_{3}\left(\mathrm{C}_{2} \mathrm{H}_{5} \mathrm{O}\right) \mathrm{Si}$ & 166 & 0.07 & 10.03 \\
\hline Molecular ion & $\mathrm{C}_{5} \mathrm{H}_{14} \mathrm{O}_{4} \mathrm{Si}^{+}$ & $\begin{array}{l}\left(\mathrm{CH}_{3} \mathrm{O}\right)_{3} \mathrm{Si}-\stackrel{+}{\circ}-\mathrm{CH}_{2}-\mathrm{CH}_{3} \\
\left(\mathrm{CH}_{3} \mathrm{O}\right)_{2}\left(\mathrm{C}_{2} \mathrm{H}_{5} \mathrm{O}\right) \mathrm{Si}-\stackrel{+}{+} \underline{\dot{\mathrm{o}}}-\mathrm{CH}_{3}\end{array}$ & 166 & 2.78 & 15.75 \\
\hline Tetramethoxysilane & $\mathrm{C}_{4} \mathrm{H}_{12} \mathrm{O}_{4} \mathrm{Si}$ & $\left(\mathrm{CH}_{3} \mathrm{O}\right)_{4} \mathrm{Si}$ & 152 & 0.01 & 10.09 \\
\hline Molecular ion & $\mathrm{C}_{4} \mathrm{H}_{12} \mathrm{O}_{4} \mathrm{Si}^{+}$ & $\left(\mathrm{CH}_{3} \mathrm{O}\right)_{4} \mathrm{Si}-\stackrel{+}{\mathrm{0}}-\mathrm{CH}_{3}$ & 152 & 3.03 & 15.15 \\
\hline
\end{tabular}


After the electron impact at $70 \mathrm{eV}$, the reaction center is located on the oxygen atom of a methoxy or ethoxy group and leads to molecular ions with comparable formation heats; for example for the TR1M transester, the difference between the formation heats for the TR1 $\mathrm{M}^{+}$ion (1) with the reaction center on the ethoxy group and the $\mathrm{TR} 1 \mathrm{M}^{+}$ion (2) with the center of reaction on the methoxy group is only $0.4 \mathrm{kcal} / \mathrm{mol}$ (Figure $3 \mathrm{~b}$ ).

The initiation center for fragmentation reactions is located at TEOS on the ethoxy group, and at tetramethoxysilane (TMOS) on the methoxy group. Tetramethoxysilane can be considered as the second reference system along with TEOS. For the other methoxy-transesters (TR1M-TR3M) the charge location can be produced, as shown in Figure $3 \mathrm{~b}$ and in Table 6, on both the ethoxy and the methoxy groups.

The preponderance of the two reaction centers in molecular ion obtained by electronic impact is dependent on the relative ratio of the ethoxy groups and the methoxy groups.

In all the molecular ions obtained from TEOS to TMOS (Figure 3a-e), charge delocalizations occur due to the electropositive nature of the silicon atom (in particular) and of the carbon atom relative to the oxygen atom. The highest stabilization by charge delocalization occurs in tetramethoxysilane (Figure 3e) which exhibits a very intense molecular ion of $58.2 \%$ of the base peak (Table 5).

The dipole moments and ionization potentials for the ionic species have higher expected values compared to the corresponding neutral species (Table 6).

\subsection{Primary events. Cleavages of $\sigma$ bonds}

The fragmentation ions obtained directly from the molecular ion by cleavage of the $\sigma$ bonds, can be clearly demonstrated experimentally by the B/E linked scan, which gives the daughter ions for the molecular ions of the TEOS methoxy-transesters. Figure 4 shows ions with m/e 179, 165, 151, 149 and 135 obtained from the molecular ion of dimethoxydiethoxysilane (TR2M). These fragmentation ions are obtained by removing the radicals $\mathrm{H}^{\circ}, \mathrm{CH}_{3}{ }^{\circ}, \mathrm{C}_{2} \mathrm{H}_{5}{ }^{\circ}, \mathrm{CH}_{3} \mathrm{O}^{\circ}$ and $\mathrm{C}_{2} \mathrm{H}_{5} \mathrm{O}^{\circ}$. The difference with the TEOS reference system is the appearance of the $\mathrm{m} / \mathrm{e} 149$ fragment by eliminating a methoxy group. The low intensity of this fragment is an indication of the small ionization ratio on the oxygen atom of the methoxy group to the ethoxy group.

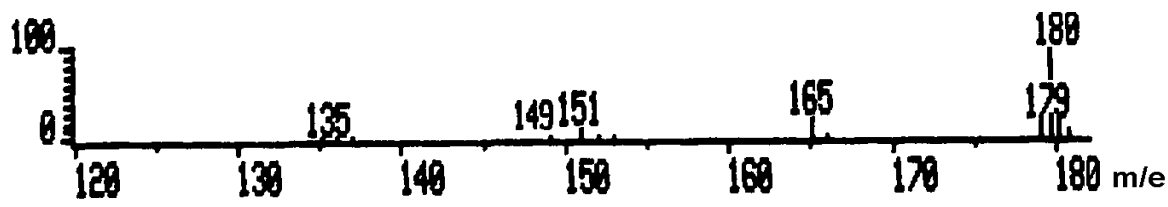

Figure 4. The daughter ions of the molecular ion of dimethoxydiethoxysilane (TR2M) obtained by the B/E linked scan

The same fragmentation reactions occur in the other methoxy-transesters with the specification that the weight of the elimination reaction of the methoxy group is increasing as the degree of transesterification increases, resulting in the obtaining of the basic ion in the mass spectrum of TMOS at $\mathrm{m} / \mathrm{e} 121$ (Table 5).

All fragmentation ions in Tables 3-5 obtained in primary processes are thickened in grey cells and the molecular ions of the TEOS methoxy-transesters in yellow cells.

The elimination of a methyl group is an intense reaction for the species containing the ethyl groups because after the cleavage a stabilized oxication is formed by the resonance effect with the formation of a carbocation as in the case of TEOS, according to the reaction (6). Thus, for the TEOS, TR1M and TR2M species, the M-15 is the basic peak in the mass spectrum, and for the TR3M species with one single ethyl group, the M-15 ion is very intense (85.4\%) (Table 2-4). For TR4M (TMOS) with four 
methyl groups, the intensity of the M-15 ion is low (7.2\%) due to obtaining an oxication that can only be stabilized by hydrogen transposition more difficult to perform (Table 5).

$$
\begin{aligned}
& \mathrm{M}^{+\cdot}-\mathrm{CH}_{3}^{\cdot} \longrightarrow \mathrm{M}-\mathrm{CH}_{3}{ }^{\top+}
\end{aligned}
$$

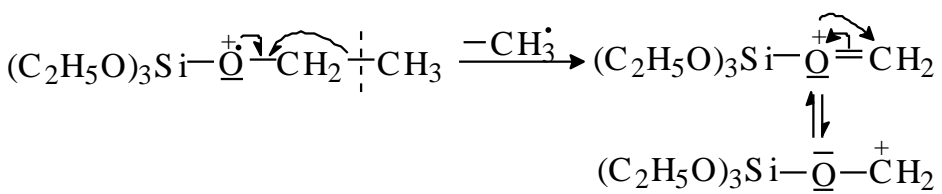

The elimination of two methoxy groups simultaneously occurs for the TR2M-TR4M species (Table 2-5) and was discussed for TMOS by Wheeler [2].

The ion of $\mathrm{m} / \mathrm{e} 90$ has the intensity $\mathrm{I}=32.3 \%$ in the mass spectrum of the tetramethoxysilane (TMOS) (Table 5; in grey cell) and can be obtained by simultaneous ionization of two oxygen atoms, due to lower shielding of the oxygen atom to the methoxy groups compared to ethoxy groups, at electron impact in ionization chamber of mass spectrometer. For tetramethoxysilane we have the reaction (7):

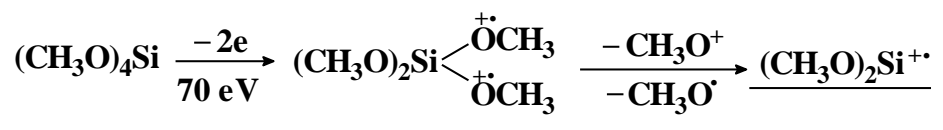

m/e 152/2

$\mathbf{m} / \mathbf{e} 90$

The obtained cation with the $\mathrm{m} / \mathrm{e} 90$ is expected to readily eliminate a $\mathrm{CH}_{3} \mathrm{O}^{\bullet}$ radical to obtain a stable siliconiu ion:

$$
\underset{\text { m/e } 90}{\left(\mathrm{CH}_{3} \mathrm{O}\right)_{2} \mathrm{Si}^{+\cdot} \stackrel{-\mathrm{CH}_{3} \mathrm{O}^{\circ}}{\longrightarrow}} \frac{\left(\mathrm{CH}_{3} \mathrm{O}\right) \mathrm{Si}^{+}}{\mathrm{m} / \mathrm{e} \mathrm{59}}
$$

The simultaneous elimination of a methoxy group and an ethoxy group through the same mechanism described by equation (7) occurs only in the TR1M-TR3M species with mixed alkoxy groups and the ionic intensity increases from $1 \%$ for the TR1M specie to $7.9 \%$ for the TR3M specie with the increase in the number of methoxy groups (Table 7; in grey cells).

The elimination of an ethyl group is more intense when the number of ethoxy groups in the TEOS methoxy-transesters is higher and the ionic intensity increases from $3.6 \%$ for the TR3M specie to $22.9 \%$ for the TEOS specie and does not occur for the TMOS specie containing only methoxy groups (Table 7; in grey cells).

Primary processes with cleavages of $\sigma$ bonds and eliminations of $\mathrm{H}^{\circ}, \mathrm{CH}_{3}{ }^{\circ}, \mathrm{C}_{2} \mathrm{H}_{5}{ }^{\circ}, \mathrm{CH}_{3} \mathrm{O}^{\circ}$ and $\mathrm{C}_{2} \mathrm{H}_{5} \mathrm{O}^{\circ}$ radicals can be an indication of the weight of the two mentioned reaction centers. For example, the elimination of a methoxy group is proportional to the number of methoxy groups in the discussed species. Thus, the ionic intensity obtained from molecular ion by removing a $\mathrm{CH}_{3} \mathrm{O}^{\circ}$ radical increase from $2.2 \%$ for TR1M to $4.3 \%$ for TR2M and to $7 \%$ for TR3M. For the TMOS molecular species containing only methoxy groups, the removal of the $\mathrm{CH}_{3} \mathrm{O}^{\circ}$ radical is an intense reaction as expected

\begin{tabular}{|c|c|c|c|c|c|c|c|c|c|c|c|c|c|}
\hline \multirow[t]{2}{*}{ Molecular species } & \multirow[t]{2}{*}{$\begin{array}{l}\text { Cod } \\
\text { name }\end{array}$} & \multirow[t]{2}{*}{$\begin{array}{l}\text { Molecular } \\
\text { formulae }\end{array}$} & \multirow[t]{2}{*}{$\begin{array}{l}\text { Molecular } \\
\text { mass }\end{array}$} & \multicolumn{2}{|c|}{$\left[\mathrm{M}_{-} \mathrm{CH}_{3}\right]^{+}$} & \multicolumn{2}{|c|}{$\left[\mathrm{M}-\mathrm{C}_{2} \mathrm{H}_{5}\right]^{+}$} & \multicolumn{2}{|c|}{$\left[\mathrm{M}-\mathrm{CH}_{3} \mathrm{O}\right]^{+}$} & \multicolumn{2}{|c|}{$\begin{array}{c}{[\mathrm{M}-} \\
\left.2 \mathrm{CH}_{3} \mathrm{O}\right]^{+}\end{array}$} & \multicolumn{2}{|c|}{$\begin{array}{c}{\left[\mathrm{M}-\mathrm{CH}_{3} \mathrm{O}-\right.} \\
\left.\mathrm{C}_{2} \mathrm{H}_{5} \mathrm{O}\right]^{+}\end{array}$} \\
\hline & & & & $\mathrm{m} / \mathrm{e}$ & $\begin{array}{c}\text { Int. } \\
\%\end{array}$ & $\mathrm{~m} / \mathrm{e}$ & $\begin{array}{c}\text { Int. } \\
\%\end{array}$ & $\mathrm{~m} / \mathrm{e}$ & $\begin{array}{l}\text { Int. } \\
\%\end{array}$ & $\mathrm{~m} / \mathrm{e}$ & $\begin{array}{c}\text { Int. } \\
\%\end{array}$ & $\mathrm{~m} / \mathrm{e}$ & Int. \% \\
\hline Tetraethoxysilane & TEOS & $\mathrm{C}_{8} \mathrm{H}_{20} \mathrm{O}_{4} \mathrm{Si}$ & 208 & 193 & 100,0 & 179 & 22.9 & - & - & - & - & - & - \\
\hline Methoxytriethoxysilane & TR1M & $\mathrm{C}_{7} \mathrm{H}_{18} \mathrm{O}_{4} \mathrm{Si}$ & 194 & 179 & 100,0 & 165 & 22.1 & 163 & 2.2 & - & - & 118 & 1.0 \\
\hline Dimethoxydiethoxysilane & TR2M & $\mathrm{C}_{6} \mathrm{H}_{16} \mathrm{O}_{4} \mathrm{Si}$ & 180 & 165 & 100,0 & 151 & 16.1 & 149 & 4.3 & 118 & 0.2 & 104 & 2.7 \\
\hline Trimethoxyethoxysilane & TR3M & $\mathrm{C}_{5} \mathrm{H}_{14} \mathrm{O}_{4} \mathrm{Si}$ & 166 & 151 & 86.4 & 137 & 3.6 & 135 & 7.0 & 104 & 1.5 & 90 & 7.9 \\
\hline Tetramethoxysilane & TMOS & $\mathrm{C}_{4} \mathrm{H}_{12} \mathrm{O}_{4} \mathrm{Si}$ & 152 & 137 & 7.4 & - & - & 121 & 100,0 & 90 & 32.3 & - & - \\
\hline
\end{tabular}
by leading to the base ion in the mass spectrum with the m/e 121 (Table 7 ; in grey cells).

Table 7. Primary events in mass spectra of the TEOS methoxy-transesters 
The comparative intensities of $\mathrm{CH}_{3} \mathrm{O}^{+}$and $\mathrm{C}_{2} \mathrm{H}_{5} \mathrm{O}^{+}$cations in the mass spectra of the TR1MTR4M species (Tables 3-5) are specified in Table 8 (grey cells).

Table 8. $\mathrm{CH}_{3} \mathrm{O}^{+}$and $\mathrm{C}_{2} \mathrm{H}_{5} \mathrm{O}^{+}$ion intensity in mass spectra of the TEOS methoxy-transesters

\begin{tabular}{|c|c|c|c|c|c|}
\hline Molecular species & $\begin{array}{c}\text { Cod } \\
\text { name }\end{array}$ & $\begin{array}{c}\text { Molecular } \\
\text { formulae }\end{array}$ & $\begin{array}{c}\text { Molecular } \\
\text { mass }\end{array}$ & $\mathrm{CH}_{3} \mathrm{O}^{+} \mathrm{m} / \mathrm{e} 31,0183$ & $\mathrm{C}_{2} \mathrm{H}_{5} \mathrm{O}^{+} \mathrm{m} / \mathrm{e} 45,0340$ \\
\hline Tetraethoxysilane & TEOS & $\mathrm{C}_{8} \mathrm{H}_{20} \mathrm{O}_{4} \mathrm{Si}$ & 208 & - & Intensity $\%$ \\
\hline Methoxytriethoxysilane & TR1M & $\mathrm{C}_{7} \mathrm{H}_{18} \mathrm{O}_{4} \mathrm{Si}$ & 194 & 0.9 & 1.0 \\
\hline Dimethoxydiethoxysilane & TR2M & $\mathrm{C}_{6} \mathrm{H}_{16} \mathrm{O}_{4} \mathrm{Si}$ & 180 & 1.0 & 0.9 \\
\hline Trimethoxyethoxysilane & TR3M & $\mathrm{C}_{5} \mathrm{H}_{14} \mathrm{O}_{4} \mathrm{Si}$ & 166 & 1.7 & 0.6 \\
\hline Tetramethoxysilane & TMOS & $\mathrm{C}_{4} \mathrm{H}_{12} \mathrm{O}_{4} \mathrm{Si}$ & 152 & 3.4 & 0.5 \\
\hline
\end{tabular}

\subsection{Eliminations of neutral molecules from primary ions and from those obtained by consecutive} elimination reactions

Emphasizing the fragmentation ions eliminating small molecules is accomplished by $(\mathrm{B} / \mathrm{E})(1-\mathrm{E})^{1 / 2}$ linked scans. The chromatograms and the mass spectra with fragmentation ions of TR1M-TR4M and TEOS which eliminate acetaldehyde, ethylene and formaldehyde are shown in Figures 5, 6, 7 respectively.

The elimination of acetaldehyde occurs mainly from the primary ions of the TEOS, TR1M-TR3M species and is even more intense as the number of ethoxy groups is higher. In Figure 5a-d, all fragmentation ions of TEOS and TR1M-TR3M that eliminate acetaldehyde are shown.

The fragmentation ions of the TEOS, TR1M and TR2M species that remove ethylene by linked scan $(B / E)(1-E)^{1 / 2}$ are shown in Figure 6.a-c. The ethylene elimination reactions are the more intense as the number of ethoxy groups in the studied species increases.

The formaldehyde removal reactions are dominant in tetramethoxysilane (TMOS) as found in the literature study [1]. These elimination reactions are experimentally confirmed by linked scan (B/E)(1E) ${ }^{1 / 2}$ and are shown in Figure 7 for (a) TMOS, (b) TR3M, (c) TR2M, (d) TR1M and (e) TEOS. The elimination of formaldehyde decreases in intensity from TMOS to TEOS by decreasing the number of methoxy groups in these species.

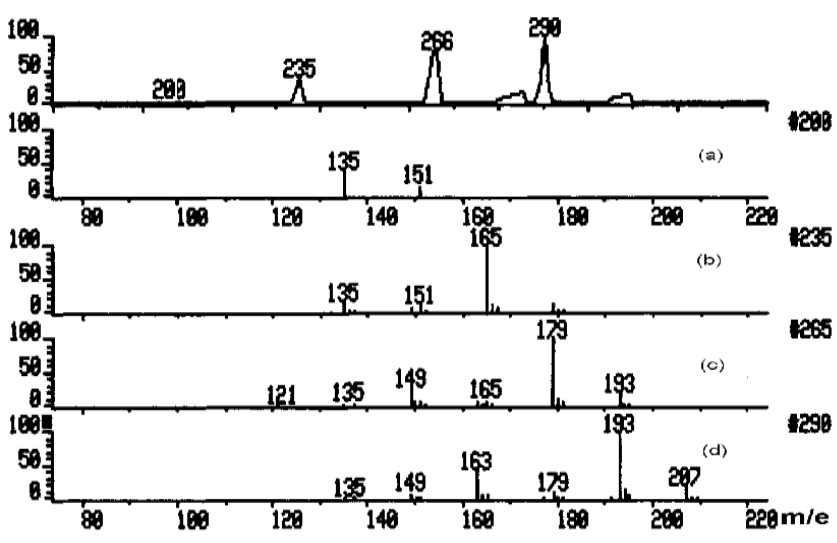

Figure 5. The fragmentation ions of the TEOS methoxy-transesters that eliminate acetaldehyde obtained by linked scan $(\mathrm{B} / \mathrm{E})(1-\mathrm{E})^{1 / 2}$ (a) TR3M, (b) TR2M, (c) TR1M and (d) TEOS

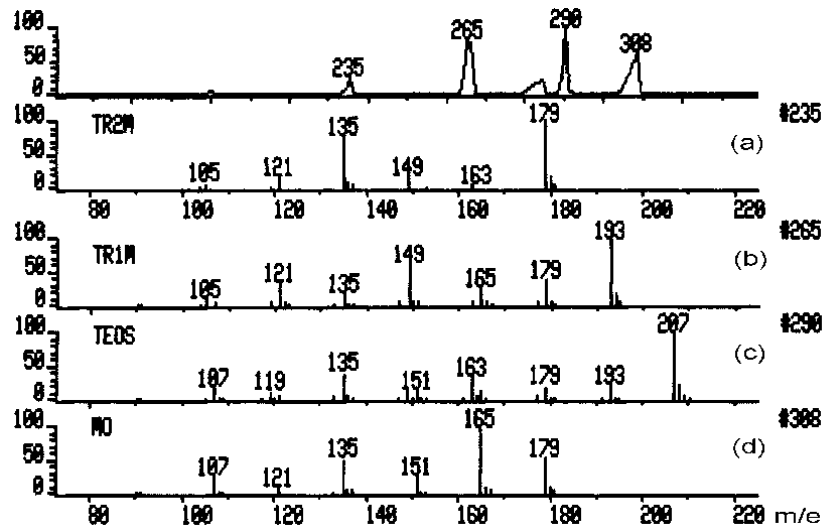

Figure 6. The fragmentation ions of the TEOS methoxy- transesters that eliminate ethylene obtained by linked scan $(\mathrm{B} / \mathrm{E})(1-$ E) ${ }^{1 / 2}$ (a) TR2M, (b) TR1M, and (c) TEOS 


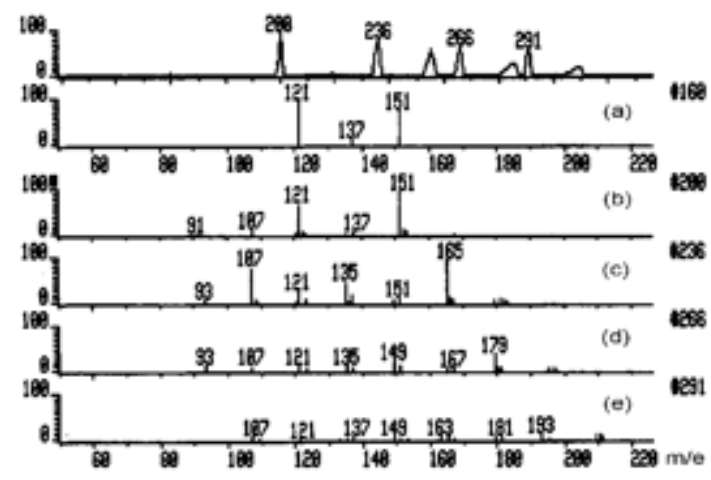

Figure 7. The fragmentation ions

of the TEOS methoxy-

transesters that eliminate

formaldehyde obtained by linked scan $(B / E)(1-E)^{1 / 2}(a)$

TR4M, (b) TR3M,

(c) TR2M, (d) TR1M and (e)

\subsection{Separation of fragmentation ions at high-resolution. Accurate mass and isotopic effects for the ions in the mass spectra of the TEOS methoxy-transesters}

The accurate mass measurements and $\mathrm{M}+1, \mathrm{M}+2$ isotopic effects of the ions in the mass spectra of TEOS, TEOS dimer and TEOS cyclic tetramer were presented in previous works [13-17]; considerations on accurate mass and isotopic effect measurements are the same for the TEOS methoxy-transesters.

A strong argument on the existence of ions in the mass spectra of molecular species TR1M-TR4M is the accurate mass measurements at high resolution $\mathrm{R}=5000$ at a pre-set error of the 10 mili mass unit (mmu). From Tables 9-12 it is found that for virtually all ions in the mass spectra of these molecular species we have differences of less than $10 \mathrm{mmu}$ between the observed and calculated masses.

An argument in favor of the existence of an ion in the mass spectrum is the $M+1, M+2$ isotopic effects measured experimentally compared to theoretically calculated values. Thus, Tables 9-12 (in grey cells) show $\mathrm{M}+1, \mathrm{M}+2$ isotopic effects of molecular ions and the most intensive fragmentation ions in the mass spectra of the TR1M-TR4M (TMOS) species. A good concordance between the experimental values of the $M+1, M+2$ isotopic effects and those calculated with the ISO dedicated program [18] is found.

The values of the double bond equivalent (DBE) for the ions of the TEOS methoxy-transesters are also shown in Tables 9-12.

Table 9. The $\mathrm{M}+1, \mathrm{M}+2$ isotopic effects, accurate mass measurements at high resolution $\mathrm{R}=5000$ and double bond equivalent (DBE) for the ions of the mass spectrum of methoxytriethoxysilane (TR1M)

\begin{tabular}{|c|c|c|c|c|c|c|c|c|}
\hline $\begin{array}{l}\text { Crt. } \\
\text { no. }\end{array}$ & Structural formulas & Ionic formulas & $\mathrm{I}_{\mathrm{EXP}} \%$ & $\mathrm{I}_{\mathrm{CALC}} \%$ & $\begin{array}{c}\text { Calculate } \\
\text { mass }\end{array}$ & $\begin{array}{l}\text { Experimental } \\
\text { mass }\end{array}$ & $\begin{array}{l}\text { Error } \\
(\mathrm{mmu})\end{array}$ & DBE \\
\hline 1. & $\left(\mathrm{CH}_{3} \mathrm{O}\right)\left(\mathrm{C}_{2} \mathrm{H}_{5} \mathrm{O}\right){ }_{3}{ }^{30} \mathrm{Si}^{+.}$ & $\mathrm{C}_{7} \mathrm{H}_{18} \mathrm{O}_{4}{ }^{30} \mathrm{Si}$ & 0.7 & 0.6 & 196.0942 & 196.0908 & 3.4 & 0 \\
\hline 2. & $\left(\mathrm{CH}_{3} \mathrm{O}\right)\left(\mathrm{C}_{2} \mathrm{H}_{5} \mathrm{O}\right)_{3}{ }^{29} \mathrm{Si}^{+}$. & $\mathrm{C}_{7} \mathrm{H}_{18} \mathrm{O}_{4}{ }^{29} \mathrm{Si}$ & 2.1 & 1.6 & 195.0970 & 195.0904 & 6.5 & 0 \\
\hline 3. & $\left(\mathrm{CH}_{3} \mathrm{O}\right)\left(\mathrm{C}_{2} \mathrm{H}_{5} \mathrm{O}\right)_{3}{ }^{28} \mathrm{Si}^{+}$. & $\mathrm{C}_{7} \mathrm{H}_{18} \mathrm{O}_{4}{ }^{28} \mathrm{Si}$ & 11.4 & $\rightarrow \quad 11.4$ & 194.0974 & 194.0953 & 2.1 & 0 \\
\hline 4. & $\left(\mathrm{CH}_{3} \mathrm{O}\right)\left(\mathrm{C}_{2} \mathrm{H}_{5} \mathrm{O}\right)_{2}{ }^{28} \mathrm{Si}-\mathrm{O}-\mathrm{C}^{+} \mathrm{H}-\mathrm{CH}_{3}$ & $\mathrm{C}_{7} \mathrm{H}_{17} \mathrm{O}_{4}{ }^{28} \mathrm{Si}$ & 6.2 & - & 193.0896 & 193.0925 & -2.9 & 0.5 \\
\hline 5. & $\left(\mathrm{CH}_{3} \mathrm{O}\right)\left(\mathrm{C}_{2} \mathrm{H}_{5} \mathrm{O}\right){ }_{2}{ }^{30} \mathrm{Si}-\mathrm{O}-\mathrm{C}^{+} \mathrm{H}_{2}$ & $\mathrm{C}_{6} \mathrm{H}_{15} \mathrm{O}_{4}{ }^{30} \mathrm{Si}$ & 7.1 & 4.8 & 181.0708 & 181.0701 & 0.7 & 0.5 \\
\hline 6. & $\left(\mathrm{CH}_{3} \mathrm{O}\right)\left(\mathrm{C}_{2} \mathrm{H}_{5} \mathrm{O}\right)_{2}{ }^{29} \mathrm{Si}-\mathrm{O}-\mathrm{C}^{+} \mathrm{H}_{2}$ & $\mathrm{C}_{6} \mathrm{H}_{15} \mathrm{O}_{4}{ }^{29} \mathrm{Si}$ & 14.0 & 12.3 & 180.0735 & 180.0762 & -2.7 & 0.5 \\
\hline 7. & $\left(\mathrm{CH}_{3} \mathrm{O}\right)\left(\mathrm{C}_{2} \mathrm{H}_{5} \mathrm{O}\right){ }_{2}{ }^{28} \mathrm{Si}-\mathrm{O}-\mathrm{C}^{+} \mathrm{H}_{2}$ & $\mathrm{C}_{6} \mathrm{H}_{15} \mathrm{O}_{4}{ }^{28} \mathrm{Si}$ & 100.0 & $\rightarrow 100.0$ & 179.0739 & 179.0745 & -0.6 & 0.5 \\
\hline 8. & $\left(\mathrm{CH}_{3} \mathrm{O}\right)_{2}\left(\mathrm{C}_{2} \mathrm{H}_{5} \mathrm{O}\right)^{28} \mathrm{Si}-\mathrm{O}-\mathrm{C}^{+}=\mathrm{CH}_{2}$ & $\mathrm{C}_{6} \mathrm{H}_{13} \mathrm{O}_{4}{ }^{28} \mathrm{Si}$ & 0.9 & - & 177.0583 & 177.0739 & $>10$ & 1.5 \\
\hline 9. & $\left(\mathrm{CH}_{3} \mathrm{O}\right)\left(\mathrm{C}_{2} \mathrm{H}_{5} \mathrm{O}\right){ }_{2}^{30} \mathrm{Si}-\mathrm{O}^{+}$ & $\mathrm{C}_{5} \mathrm{H}_{13} \mathrm{O}_{4}{ }^{30} \mathrm{Si}$ & 1.3 & 0.9 & 167.0551 & 167.0792 & $>10$ & 0.5 \\
\hline 10. & $\left(\mathrm{CH}_{3} \mathrm{O}\right)\left(\mathrm{C}_{2} \mathrm{H}_{5} \mathrm{O}\right)_{2}{ }^{29} \mathrm{Si}-\mathrm{O}^{+}$ & $\mathrm{C}_{5} \mathrm{H}_{13} \mathrm{O}_{4}{ }^{29} \mathrm{Si}$ & 2.8 & 2.0 & 166.0585 & 166.0665 & -8.0 & 0.5 \\
\hline 11. & $\left(\mathrm{CH}_{3} \mathrm{O}\right)\left(\mathrm{C}_{2} \mathrm{H}_{5} \mathrm{O}\right){ }_{2}^{28} \mathrm{Si}-\mathrm{O}^{+}$ & $\mathrm{C}_{5} \mathrm{H}_{13} \mathrm{O}_{4}{ }^{28} \mathrm{Si}$ & 18.3 & 18.3 & 165.0582 & 165.0594 & -1.2 & 0.5 \\
\hline 12. & $\left(\mathrm{C}_{2} \mathrm{H}_{5} \mathrm{O}\right)_{3}{ }^{29} \mathrm{Si}^{+}$ & $\mathrm{C}_{6} \mathrm{H}_{15} \mathrm{O}_{3}{ }^{29} \mathrm{Si}$ & 0.4 & & 164.0785 & 164.0725 & 6.0 & 0.5 \\
\hline 13. & $\left(\mathrm{C}_{2} \mathrm{H}_{5} \mathrm{O}\right)_{3}{ }^{28} \mathrm{Si}^{+}$ & $\mathrm{C}_{6} \mathrm{H}_{15} \mathrm{O}_{3}{ }^{28} \mathrm{Si}$ & 2.1 & 2.1 & 163.0790 & 163.0740 & 5.0 & 0.5 \\
\hline 14. & $\left(\mathrm{CH}_{3} \mathrm{O}\right)_{2}\left(\mathrm{C}_{2} \mathrm{H}_{5} \mathrm{O}\right)^{28} \mathrm{Si}-\mathrm{O}^{+}$ & $\mathrm{C}_{4} \mathrm{H}_{11} \mathrm{O}_{4}{ }^{28} \mathrm{Si}$ & 8.8 & & 151.0426 & 151.0477 & -5.1 & 0.5 \\
\hline 15. & $\left(\mathrm{CH}_{3} \mathrm{O}\right)\left(\mathrm{C}_{2} \mathrm{H}_{5} \mathrm{O}\right)_{2}{ }^{30} \mathrm{Si}^{+}$ & $\mathrm{C}_{5} \mathrm{H}_{13} \mathrm{O}_{3}{ }^{30} \mathrm{Si}$ & $\uparrow+$ & 2.3 & 151.0602 & 151.0601 & 0.1 & 0.5 \\
\hline 16. & $\left(\mathrm{CH}_{3} \mathrm{O}\right)\left(\mathrm{C}_{2} \mathrm{H}_{5} \mathrm{O}\right)_{2}{ }^{29} \mathrm{Si}^{+}$ & $\mathrm{C}_{5} \mathrm{H}_{13} \mathrm{O}_{3}{ }^{29} \mathrm{Si}$ & 6.0 & 5.7 & 150.0629 & 150.0661 & -3.2 & 0.5 \\
\hline 17. & $\left(\mathrm{CH}_{3} \mathrm{O}\right)\left(\mathrm{C}_{2} \mathrm{H}_{5} \mathrm{O}\right){ }_{2}^{28} \mathrm{Si}^{+}$ & $\mathrm{C}_{5} \mathrm{H}_{13} \mathrm{O}_{3}{ }^{28} \mathrm{Si}$ & 55.9 & 55.9 & 149.0633 & 149.0641 & -0.8 & 0.5 \\
\hline 18. & $\left(\mathrm{CH}_{3} \mathrm{O}\right)\left(\mathrm{C}_{2} \mathrm{H}_{5} \mathrm{O}\right)(\mathrm{H}){ }^{28} \mathrm{Si}-\mathrm{O}-\mathrm{C}^{+}=\mathrm{CH}_{2}$ & $\mathrm{C}_{5} \mathrm{H}_{11} \mathrm{O}_{3}{ }^{28} \mathrm{Si}$ & 0.6 & - & 147.0477 & 147.0425 & 5.2 & 1.5 \\
\hline 19. & $\left(\mathrm{CH}_{3} \mathrm{O}\right)_{2}\left(\mathrm{C}_{2} \mathrm{H}_{5} \mathrm{O}\right)^{30} \mathrm{~S}^{\mathrm{i}+}$ & $\mathrm{C}_{4} \mathrm{H}_{11} \mathrm{O}_{3}{ }^{30} \mathrm{Si}$ & $6.7+$ & 2.5 & 137.0445 & 137.0445 & 6.6 & 0.5 \\
\hline
\end{tabular}




\begin{tabular}{|c|c|c|c|c|c|c|c|c|}
\hline 20. & $\left(\mathrm{CH}_{3} \mathrm{O}\right)_{2}\left(\mathrm{C}_{2} \mathrm{H}_{5} \mathrm{O}\right){ }^{29} \mathrm{Si}^{+}$ & $\mathrm{C}_{4} \mathrm{H}_{11} \mathrm{O}_{3}{ }^{29} \mathrm{Si}$ & 5.6 & 5.7 & 136.0473 & 136.0548 & -7.5 & 0.5 \\
\hline 21. & $\left(\mathrm{CH}_{3} \mathrm{O}\right)_{2}\left(\mathrm{C}_{2} \mathrm{H}_{5} \mathrm{O}\right)^{28} \mathrm{Si}^{+}$ & $\mathrm{C}_{4} \mathrm{H}_{11} \mathrm{O}_{3}{ }^{28} \mathrm{Si}$ & 58.4 & $\rightarrow \quad 58.4$ & 135.0477 & 135.0518 & -4.1 & 0.5 \\
\hline 22. & $\left(\mathrm{CH}_{3} \mathrm{O}\right)\left(\mathrm{C}_{2} \mathrm{H}_{5} \mathrm{O}\right)(\mathrm{OH}){ }^{30} \mathrm{Si}^{+}$ & $\mathrm{C}_{3} \mathrm{H}_{9} \mathrm{O}_{3}{ }^{30} \mathrm{Si}$ & 1.5 & 0.9 & 123.0289 & 123.0288 & 0.1 & 0.5 \\
\hline 23. & $\left(\mathrm{CH}_{3} \mathrm{O}\right)\left(\mathrm{C}_{2} \mathrm{H}_{5} \mathrm{O}\right)(\mathrm{OH}){ }^{29} \mathrm{Si}^{+}$ & $\mathrm{C}_{3} \mathrm{H}_{9} \mathrm{O}_{3}{ }^{29} \mathrm{Si}$ & 1.7 & 1.5 & 122.0316 & 122.0349 & -3.3 & 0.5 \\
\hline 24. & $\left(\mathrm{CH}_{3} \mathrm{O}\right)\left(\mathrm{C}_{2} \mathrm{H}_{5} \mathrm{O}\right)(\mathrm{OH}){ }^{28} \mathrm{Si}^{+}$ & $\mathrm{C}_{3} \mathrm{H}_{9} \mathrm{O}_{3}{ }^{28} \mathrm{Si}$ & 18.1 & $\rightarrow \quad 18.1$ & 121.0320 & 121.0340 & -2.0 & 0.5 \\
\hline 25. & $\left(\mathrm{CH}_{3} \mathrm{O}\right)\left(\mathrm{C}_{2} \mathrm{H}_{5} \mathrm{O}\right)(\mathrm{H}){ }^{30} \mathrm{Si}^{+}$ & $\mathrm{C}_{3} \mathrm{H}_{9} \mathrm{O}_{2}{ }^{30} \mathrm{Si}$ & 1.1 & 0.9 & 107.0340 & 107.0276 & 6.4 & 0.5 \\
\hline 26. & $\left(\mathrm{CH}_{3} \mathrm{O}\right)\left(\mathrm{C}_{2} \mathrm{H}_{5} \mathrm{O}\right)(\mathrm{H})^{29} \mathrm{Si}^{+}$ & $\mathrm{C}_{3} \mathrm{H}_{9} \mathrm{O}_{2}{ }^{29} \mathrm{Si}$ & 2.0 & 1.9 & 106.0367 & 106.0413 & -4.6 & 0.5 \\
\hline 27. & $\left(\mathrm{CH}_{3} \mathrm{O}\right)\left(\mathrm{C}_{2} \mathrm{H}_{5} \mathrm{O}\right)(\mathrm{H}){ }^{28} \mathrm{Si}^{+}$ & $\mathrm{C}_{3} \mathrm{H}_{9} \mathrm{O}_{2}{ }^{28} \mathrm{Si}$ & 22.4 & $\rightarrow \quad 22.4$ & 105.0371 & 105.0405 & -3.4 & 0.5 \\
\hline 28. & $\left(\mathrm{CH}_{3} \mathrm{O}\right)(\mathrm{HO})_{2}{ }^{30} \mathrm{Si}^{+}$ & $\mathrm{CH}_{5} \mathrm{O}_{3}{ }^{30} \mathrm{Si}$ & 0.9 & 0.8 & 94.9976 & 94.9941 & 3.5 & 0.5 \\
\hline 29. & $\left(\mathrm{CH}_{3} \mathrm{O}\right)(\mathrm{HO})_{2}{ }^{29} \mathrm{Si}^{+}$ & $\mathrm{CH}_{5} \mathrm{O}_{3}{ }^{29} \mathrm{Si}$ & 1.2 & 1.2 & 94.0003 & 93.9942 & 6.1 & 0.5 \\
\hline 30. & $\left(\mathrm{CH}_{3} \mathrm{O}\right)(\mathrm{HO})_{2}{ }^{28} \mathrm{Si}^{+}$ & $\mathrm{CH}_{5} \mathrm{O}_{3}{ }^{28} \mathrm{Si}$ & 18.5 & $\rightarrow \quad 18.5$ & 93.0007 & 92.9951 & 5.6 & 0.5 \\
\hline 31. & $\left(\mathrm{C}_{2} \mathrm{H}_{5} \mathrm{O}\right)(\mathrm{OH})(\mathrm{H}){ }^{28} \mathrm{Si}^{+}$. & $\mathrm{C}_{2} \mathrm{H}_{7} \mathrm{O}_{2}{ }^{28} \mathrm{Si}$ & 4.9 & - & 91.0215 & 91.0258 & -4.3 & 0.5 \\
\hline 32. & $\left(\mathrm{CH}_{3} \mathrm{O}\right)(\mathrm{HO})(\mathrm{H})^{28} \mathrm{Si}^{+}$ & $\mathrm{CH}_{5} \mathrm{O}_{2}{ }^{28} \mathrm{Si}$ & 13.7 & - & 77.0059 & 77.0093 & -3.4 & 0.5 \\
\hline 33. & $(\mathrm{OH})_{2}(\mathrm{H})^{28} \mathrm{Si}^{+}$ & $\mathrm{H}_{3} \mathrm{O}_{2}{ }^{28} \mathrm{Si}$ & 19.0 & - & 62.9902 & 62.9914 & -1.2 & 0.5 \\
\hline 34. & $(\mathrm{OH}){ }^{28} \mathrm{Si}^{+}$ & $\mathrm{HO}^{28} \mathrm{Si}$ & 5.8 & - & 44.9796 & 44.9821 & -2.5 & 0.5 \\
\hline 35. & $\mathrm{C}_{2} \mathrm{H}_{5}{ }^{+}$ & $\mathrm{C}_{2} \mathrm{H}_{5}$ & 2.7 & - & 29.0390 & 29.0415 & -2.5 & 0.5 \\
\hline
\end{tabular}

Table 10. The $\mathrm{M}+1, \mathrm{M}+2$ isotopic effects, accurate mass measurements at high resolution $\mathrm{R}=5000$ and double bond equivalent (DBE) for the ions of the mass spectrum of dimethoxydiethoxysilane (TR2M)

\begin{tabular}{|c|c|c|c|c|c|c|c|c|}
\hline $\begin{array}{l}\text { Crt. } \\
\text { no. }\end{array}$ & Structural formulas & Ionic formulas & $\mathrm{I}_{\mathrm{EXP}} \%$ & $\mathrm{I}_{\mathrm{CALC}} \%$ & $\begin{array}{c}\text { Calculate } \\
\text { mass }\end{array}$ & $\begin{array}{l}\text { Experimental } \\
\text { mass }\end{array}$ & $\begin{array}{c}\text { Error } \\
(\mathrm{mmu})\end{array}$ & $\mathrm{DBE}$ \\
\hline 1. & $\left(\mathrm{CH}_{3} \mathrm{O}\right)_{2}\left(\mathrm{C}_{2} \mathrm{H}_{5} \mathrm{O}\right)_{2}{ }^{30} \mathrm{Si}^{+.}$ & $\mathrm{C}_{6} \mathrm{H}_{16} \mathrm{O}_{4}{ }^{30} \mathrm{Si}$ & 0.5 & 0.4 & 182.0786 & 182.0741 & 4.5 & 0 \\
\hline 2. & $\left(\mathrm{CH}_{3} \mathrm{O}\right)_{2}\left(\mathrm{C}_{2} \mathrm{H}_{5} \mathrm{O}\right)_{2}{ }^{29} \mathrm{Si}^{+.}$ & $\mathrm{C}_{6} \mathrm{H}_{16} \mathrm{O}_{4}{ }^{29} \mathrm{Si}$ & 1.3 & 1.1 & 181.0813 & 181.0803 & 1.0 & 0 \\
\hline 3. & $\left(\mathrm{CH}_{3} \mathrm{O}\right)_{2}\left(\mathrm{C}_{2} \mathrm{H}_{5} \mathrm{O}\right)_{2}{ }^{28} \mathrm{Si}^{+.}$ & $\mathrm{C}_{6} \mathrm{H}_{16} \mathrm{O}_{4}{ }^{28} \mathrm{Si}$ & 8.9 & 8.9 & 180.0817 & 180.0909 & -9.2 & 0 \\
\hline 4. & $\left(\mathrm{CH}_{3} \mathrm{O}\right)_{2}\left(\mathrm{C}_{2} \mathrm{H}_{5} \mathrm{O}\right){ }^{28} \mathrm{Si}-\mathrm{O}-\mathrm{C}^{+} \mathrm{H}-\mathrm{CH}_{3}$ & $\mathrm{C}_{6} \mathrm{H}_{15} \mathrm{O}_{4}{ }^{28} \mathrm{Si}$ & 5.1 & & 179.0739 & 179.0783 & -4.4 & 0.5 \\
\hline 5. & $\left(\mathrm{CH}_{3} \mathrm{O}\right)_{2}\left(\mathrm{C}_{2} \mathrm{H}_{5} \mathrm{O}\right){ }^{30} \mathrm{Si}-\mathrm{O}-\mathrm{C}^{+} \mathrm{H}_{2}$ & $\mathrm{C}_{5} \mathrm{H}_{13} \mathrm{O}_{4}{ }^{30} \mathrm{Si}$ & 4.4 & 4.6 & 167.0551 & 167.0566 & -1.5 & 0.5 \\
\hline 6. & $\left(\mathrm{CH}_{3} \mathrm{O}\right)_{2}\left(\mathrm{C}_{2} \mathrm{H}_{5} \mathrm{O}\right){ }^{29} \mathrm{Si}-\mathrm{O}-\mathrm{C}^{+} \mathrm{H}_{2}$ & $\mathrm{C}_{5} \mathrm{H}_{13} \mathrm{O}_{4}{ }^{29} \mathrm{Si}$ & 10.5 & 11.0 & 166.0578 & 166.0579 & -0.1 & 0.5 \\
\hline 7. & $\left(\mathrm{CH}_{3} \mathrm{O}\right)_{2}\left(\mathrm{C}_{2} \mathrm{H}_{5} \mathrm{O}\right){ }^{28} \mathrm{Si}-\mathrm{O}-\mathrm{C}^{+} \mathrm{H}_{2}$ & $\mathrm{C}_{5} \mathrm{H}_{13} \mathrm{O}_{4}{ }^{28} \mathrm{Si}$ & 100.0 & $\rightarrow 100.0$ & 165.0583 & 165.0554 & 2.9 & 0.5 \\
\hline 8. & $\left(\mathrm{CH}_{3} \mathrm{O}\right)_{2}\left(\mathrm{C}_{2} \mathrm{H}_{5} \mathrm{O}\right)^{30} \mathrm{Si}-\mathrm{O}^{+}$ & $\mathrm{C}_{4} \mathrm{H}_{11} \mathrm{O}_{4}{ }^{30} \mathrm{Si}$ & 1.1 & 0.6 & 153.0395 & 153.0364 & 3.1 & 0.5 \\
\hline 9. & $\left(\mathrm{CH}_{3} \mathrm{O}\right)_{2}\left(\mathrm{C}_{2} \mathrm{H}_{5} \mathrm{O}\right)^{29} \mathrm{Si}-\mathrm{O}^{+}$ & $\mathrm{C}_{4} \mathrm{H}_{11} \mathrm{O}_{4}{ }^{29} \mathrm{Si}$ & 1.9 & 1.3 & 152.0422 & 152.0354 & 6.8 & 0.5 \\
\hline 10. & $\left(\mathrm{CH}_{3} \mathrm{O}\right)_{2}\left(\mathrm{C}_{2} \mathrm{H}_{5} \mathrm{O}\right)^{28} \mathrm{Si}-\mathrm{O}^{+}$ & $\mathrm{C}_{4} \mathrm{H}_{11} \mathrm{O}_{4}{ }^{28} \mathrm{Si}$ & 13.3 & $\rightarrow \quad 13.3$ & 151.0426 & 151.0483 & -5.7 & 0.5 \\
\hline 11. & $\left(\mathrm{CH}_{3} \mathrm{O}\right)\left(\mathrm{C}_{2} \mathrm{H}_{5} \mathrm{O}\right){ }_{2}{ }^{28} \mathrm{Si}^{+}$ & $\mathrm{C}_{5} \mathrm{H}_{13} \mathrm{O}_{3}{ }^{28} \mathrm{Si}$ & 3.9 & - & 149.0633 & 149.0583 & 5.1 & 0.5 \\
\hline 12. & $\left(\mathrm{C}_{2} \mathrm{H}_{5} \mathrm{O}\right)(\mathrm{OH})_{2}{ }^{28} \mathrm{Si}^{+.}$ & $\mathrm{C}_{3} \mathrm{H}_{9} \mathrm{O}_{4}{ }^{28} \mathrm{Si}$ & 5.0 & - & 137.0269 & 137.0360 & -9.1 & 0.5 \\
\hline 13. & $\left(\mathrm{CH}_{3} \mathrm{O}\right)_{2}\left(\mathrm{C}_{2} \mathrm{H}_{5} \mathrm{O}\right){ }^{30} \mathrm{~S}^{\mathrm{i}+}$ & $\mathrm{C}_{4} \mathrm{H}_{11} \mathrm{O}_{3}{ }^{30} \mathrm{Si}$ & $\uparrow+$ & 2.4 & 137.0445 & 137.0454 & -0.9 & 0.5 \\
\hline 14. & $\left(\mathrm{CH}_{3} \mathrm{O}\right)_{2}\left(\mathrm{C}_{2} \mathrm{H}_{5} \mathrm{O}\right){ }^{29} \mathrm{Si}^{+}$ & $\mathrm{C}_{4} \mathrm{H}_{11} \mathrm{O}_{3}{ }^{29} \mathrm{Si}$ & 5.3 & 5.3 & 136.0473 & 136.0534 & -6.2 & 0.5 \\
\hline 15. & $\left(\mathrm{CH}_{3} \mathrm{O}\right)_{2}\left(\mathrm{C}_{2} \mathrm{H}_{5} \mathrm{O}\right){ }^{28} \mathrm{Si}^{+}$ & $\mathrm{C}_{4} \mathrm{H}_{11} \mathrm{O}_{3}{ }^{28} \mathrm{Si}$ & 53.8 & $\rightarrow 53.8$ & 135.0477 & 135.0530 & -5.3 & 0.5 \\
\hline 16. & $\left(\mathrm{CH}_{3} \mathrm{O}\right)_{2}(\mathrm{H}){ }^{28} \mathrm{Si}-\mathrm{O}-\mathrm{C}^{+}=\mathrm{CH}_{2}$ & $\mathrm{C}_{4} \mathrm{H}_{9} \mathrm{O}_{3}{ }^{28} \mathrm{Si}$ & 1.3 & - & 133.0320 & 133.0369 & -4.9 & 1.5 \\
\hline 17. & $\left(\mathrm{CH}_{3} \mathrm{O}\right)\left(\mathrm{C}_{2} \mathrm{H}_{5} \mathrm{O}\right)(\mathrm{OH}){ }^{30} \mathrm{Si}^{+}$ & $\mathrm{C}_{3} \mathrm{H}_{9} \mathrm{O}_{3}{ }^{30} \mathrm{Si}$ & 1.9 & 1.7 & 123.0289 & 123.0325 & -3.6 & 0.5 \\
\hline 18. & $\left(\mathrm{CH}_{3} \mathrm{O}\right)\left(\mathrm{C}_{2} \mathrm{H}_{5} \mathrm{O}\right)(\mathrm{OH}){ }^{29} \mathrm{Si}^{+}$ & $\mathrm{C}_{3} \mathrm{H}_{9} \mathrm{O}_{3}{ }^{29} \mathrm{Si}$ & 3.7 & 3.6 & 122.0316 & 122.0396 & -8.0 & 0.5 \\
\hline 19. & $\left(\mathrm{CH}_{3} \mathrm{O}\right)\left(\mathrm{C}_{2} \mathrm{H}_{5} \mathrm{O}\right)(\mathrm{OH}){ }^{28} \mathrm{Si}^{+}$ & $\mathrm{C}_{3} \mathrm{H}_{9} \mathrm{O}_{3}{ }^{28} \mathrm{Si}$ & 41.4 & $\rightarrow 41.4$ & 121.0320 & 121.0377 & -5.7 & 0.5 \\
\hline 20. & $\left(\mathrm{CH}_{3} \mathrm{O}\right)_{2}(\mathrm{OH})^{30} \mathrm{Si}^{+}$ & $\mathrm{C}_{2} \mathrm{H}_{7} \mathrm{O}_{3}{ }^{30} \mathrm{Si}$ & 1.4 & 1.1 & 109.0132 & 109.0199 & -6.7 & 0.5 \\
\hline 21. & $\left(\mathrm{CH}_{3} \mathrm{O}\right)_{2}(\mathrm{OH})^{29} \mathrm{Si}^{+}$ & $\mathrm{C}_{2} \mathrm{H}_{7} \mathrm{O}_{3}{ }^{29} \mathrm{Si}$ & 2.0 & 2.0 & 108.0160 & 108.0250 & -9.0 & 0.5 \\
\hline 22. & $\left(\mathrm{CH}_{3} \mathrm{O}\right)_{2}(\mathrm{OH})^{28} \mathrm{Si}^{+}$ & $\mathrm{C}_{2} \mathrm{H}_{7} \mathrm{O}_{3}{ }^{28} \mathrm{Si}$ & 26.8 & $\rightarrow 26.8$ & 107.0164 & 107.0244 & -8.0 & 0.5 \\
\hline 23. & $\left(\mathrm{CH}_{3} \mathrm{O}\right)\left(\mathrm{C}_{2} \mathrm{H}_{5} \mathrm{O}\right)(\mathrm{H}){ }^{28} \mathrm{Si}^{+}$ & $\mathrm{C}_{3} \mathrm{H}_{9} \mathrm{O}_{2}{ }^{28} \mathrm{Si}$ & 8.7 & - & 105.0371 & 105.0392 & -2.1 & 0.5 \\
\hline 24. & $\left(\mathrm{CH}_{3} \mathrm{O}\right)(\mathrm{OH})_{2}{ }^{28} \mathrm{Si}^{+}$ & $\mathrm{CH}_{5} \mathrm{O}_{3}{ }^{28} \mathrm{Si}$ & 6.8 & - & 93.0008 & 93.0059 & -5.1 & 0.5 \\
\hline 25. & $\left(\mathrm{CH}_{3} \mathrm{O}\right)_{2}(\mathrm{H})^{30} \mathrm{Si}^{+}$ & $\mathrm{C}_{2} \mathrm{H}_{7} \mathrm{O}_{2}{ }^{30} \mathrm{Si}$ & 0.8 & 0.8 & 93.0183 & 93.0125 & 5.8 & $0 . .5$ \\
\hline 26. & $\left(\mathrm{CH}_{3} \mathrm{O}\right)_{2}(\mathrm{H})^{29} \mathrm{Si}^{+}$ & $\mathrm{C}_{2} \mathrm{H}_{7} \mathrm{O}_{2}{ }^{29} \mathrm{Si}$ & 1.6 & 1.5 & 92.0211 & 92.0243 & -3.2 & 0.5 \\
\hline 27. & $\left(\mathrm{CH}_{3} \mathrm{O}\right)_{2}(\mathrm{H})^{28} \mathrm{Si}^{+}$ & $\mathrm{C}_{2} \mathrm{H}_{7} \mathrm{O}_{2}{ }^{28} \mathrm{Si}$ & 20.1 & $\rightarrow 20.1$ & 91.0215 & 91.0249 & -3.4 & 0.5 \\
\hline 28. & $\left(\mathrm{CH}_{3} \mathrm{O}\right)(\mathrm{OH})(\mathrm{H}){ }^{30} \mathrm{Si}^{+}$ & $\mathrm{CH}_{5} \mathrm{O}_{2}{ }^{30} \mathrm{Si}$ & 0.8 & 0.7 & 79.0027 & 79.0024 & 0.3 & 0.5 \\
\hline 29. & $\left(\mathrm{CH}_{3} \mathrm{O}\right)(\mathrm{OH})(\mathrm{H}){ }^{29} \mathrm{Si}^{+}$ & $\mathrm{CH}_{5} \mathrm{O}_{2}{ }^{29} \mathrm{Si}$ & 1.5 & 1.2 & 78.0054 & 78.0134 & -8.0 & 0.5 \\
\hline 30. & $\left(\mathrm{CH}_{3} \mathrm{O}\right)(\mathrm{OH})(\mathrm{H}){ }^{28} \mathrm{Si}^{+}$ & $\mathrm{CH}_{5} \mathrm{O}_{2}{ }^{28} \mathrm{Si}$ & 19.4 & $\rightarrow 19.4$ & 77.0058 & 77.0140 & -8.2 & 0.5 \\
\hline 31. & $(\mathrm{OH})_{2}(\mathrm{H})^{28} \mathrm{Si}^{+}$ & $\mathrm{H}_{3} \mathrm{O}_{2}{ }^{28} \mathrm{Si}$ & 8.5 & - & 62.9902 & 62.9918 & -1.6 & 0.5 \\
\hline 32. & $\left(\mathrm{CH}_{3} \mathrm{O}\right)(\mathrm{H})_{2}{ }^{28} \mathrm{Si}^{+}$ & $\mathrm{CH}_{5} \mathrm{O}^{28} \mathrm{Si}$ & 2.3 & - & 61.0109 & 61.0053 & 5.6 & 0.5 \\
\hline 33. & $\left(\mathrm{CH}_{3} \mathrm{O}\right){ }^{28} \mathrm{Si}^{+}$ & $\mathrm{CH}_{3} \mathrm{O}^{28} \mathrm{Si}$ & 5.9 & - & 58.9953 & 58.9965 & -1.2 & 0.5 \\
\hline 34. & $(\mathrm{OH}){ }^{28} \mathrm{Si}^{+}$ & $\mathrm{HO}^{28} \mathrm{Si}$ & 5.2 & - & 44.9796 & 44.9819 & -2.2 & 0.5 \\
\hline 35. & $\mathrm{C}_{2} \mathrm{H}_{5}{ }^{+}$ & $\mathrm{C}_{2} \mathrm{H}_{5}$ & 1.2 & - & 29.0390 & 29.0398 & -0.7 & 0.5 \\
\hline
\end{tabular}


Table 11. The $\mathrm{M}+1, \mathrm{M}+2$ isotopic effects, accurate mass measurements at high resolution $\mathrm{R}=5000$ and double bond equivalent (DBE) for the ions of the mass spectrum of trimethoxyethoxysilane (TR3M)

\begin{tabular}{|c|c|c|c|c|c|c|c|c|}
\hline $\begin{array}{l}\text { Crt. } \\
\text { no. }\end{array}$ & Structural formulas & $\begin{array}{c}\text { Ionic } \\
\text { formulas }\end{array}$ & $\mathrm{I}_{\mathrm{EXP}} \%$ & $\mathrm{I}_{\mathrm{CALC}} \%$ & $\begin{array}{c}\text { Calculate } \\
\text { mass }\end{array}$ & $\begin{array}{c}\text { Experimental } \\
\text { mass }\end{array}$ & $\begin{array}{l}\text { Error } \\
(\mathrm{mmu})\end{array}$ & $\mathrm{DBE}$ \\
\hline 1. & $\left(\mathrm{CH}_{3} \mathrm{O}\right)_{3}\left(\mathrm{C}_{2} \mathrm{H}_{5} \mathrm{O}\right){ }^{30} \mathrm{Si}^{+}$. & $\mathrm{C}_{5} \mathrm{H}_{14} \mathrm{O}_{4}{ }^{30} \mathrm{Si}$ & 0.4 & 0.3 & 168.0629 & 168.0529 & 10.0 & 0 \\
\hline 2. & $\left(\mathrm{CH}_{3} \mathrm{O}\right)_{3}\left(\mathrm{C}_{2} \mathrm{H}_{5} \mathrm{O}\right)^{29} \mathrm{Si}^{+.}$ & $\mathrm{C}_{5} \mathrm{H}_{14} \mathrm{O}_{4}{ }^{29} \mathrm{Si}$ & 1.0 & 0.8 & 167.0657 & 167.0668 & -1.1 & 0 \\
\hline 3. & $\left(\mathrm{CH}_{3} \mathrm{O}\right)_{3}\left(\mathrm{C}_{2} \mathrm{H}_{5} \mathrm{O}\right){ }^{28} \mathrm{Si}^{+}$. & $\mathrm{C}_{5} \mathrm{H}_{14} \mathrm{O}_{4}{ }^{28} \mathrm{Si}$ & 7.3 & 7.3 & 166.0661 & 166.0659 & 0.2 & 0 \\
\hline 4. & $\left(\mathrm{CH}_{3} \mathrm{O}\right)_{3}{ }^{28} \mathrm{Si}-\mathrm{O}-\mathrm{C}^{+} \mathrm{H}-\mathrm{CH}_{3}$ & $\mathrm{C}_{5} \mathrm{H}_{13} \mathrm{O}_{4}{ }^{28} \mathrm{Si}$ & 5.0 & - & 165.0582 & 165.0617 & -3.5 & 0.5 \\
\hline 5. & $\left(\mathrm{CH}_{3} \mathrm{O}\right)_{3}{ }^{30} \mathrm{Si}-\mathrm{O}-\mathrm{C}^{+} \mathrm{H}_{2}$ & $\mathrm{C}_{4} \mathrm{H}_{11} \mathrm{O}_{4}{ }^{30} \mathrm{Si}$ & 4.7 & 4.5 & 153.0395 & 153.0422 & -2.7 & 1.5 \\
\hline 6. & $\left(\mathrm{CH}_{3} \mathrm{O}\right)_{3}{ }^{29} \mathrm{Si}-\mathrm{O}-\mathrm{C}^{+} \mathrm{H}_{2}$ & $\mathrm{C}_{4} \mathrm{H}_{11} \mathrm{O}_{4}{ }^{29} \mathrm{Si}$ & 9.5 & 9.9 & 152.0422 & 152.0442 & -2.0 & 0.5 \\
\hline 7. & $\left(\mathrm{CH}_{3} \mathrm{O}\right)_{3}{ }^{28} \mathrm{Si}-\mathrm{O}-\mathrm{C}^{+} \mathrm{H}_{2}$ & $\mathrm{C}_{4} \mathrm{H}_{11} \mathrm{O}_{4}{ }^{28} \mathrm{Si}$ & 100.0 & $\rightarrow 100.0$ & 151.0426 & 151.0420 & 0.6 & 0.5 \\
\hline 8. & $\left(\mathrm{CH}_{3} \mathrm{O}\right)_{3}{ }^{28} \mathrm{Si}-\mathrm{O}^{+}$ & $\mathrm{C}_{3} \mathrm{H}_{9} \mathrm{O}_{4}{ }^{28} \mathrm{Si}$ & 3.2 & - & 137.0269 & 137.0245 & 2.4 & 0.5 \\
\hline 9. & $\left(\mathrm{CH}_{3} \mathrm{O}\right)_{2}\left(\mathrm{C}_{2} \mathrm{H}_{5} \mathrm{O}\right){ }^{30} \mathrm{~S}^{\mathrm{i}+}$ & $\mathrm{C}_{4} \mathrm{H}_{11} \mathrm{O}_{3}{ }^{30} \mathrm{Si}$ & $\uparrow+$ & 0.3 & 137.0445 & 137.0340 & $>10$ & 0.5 \\
\hline 11. & $\left(\mathrm{CH}_{3} \mathrm{O}\right)_{2}\left(\mathrm{C}_{2} \mathrm{H}_{5} \mathrm{O}\right){ }^{29} \mathrm{Si}^{+}$ & $\mathrm{C}_{4} \mathrm{H}_{11} \mathrm{O}_{3}{ }^{29} \mathrm{Si}$ & 0.7 & 0.7 & 136.0473 & 136.0494 & -2.1 & 0.5 \\
\hline 12. & $\left(\mathrm{CH}_{3} \mathrm{O}\right)_{2}\left(\mathrm{C}_{2} \mathrm{H}_{5} \mathrm{O}\right){ }^{28} \mathrm{Si}^{+}$ & $\mathrm{C}_{4} \mathrm{H}_{11} \mathrm{O}_{3}{ }^{28} \mathrm{Si}$ & 7.5 & 7.5 & 135.0477 & 135.0459 & 1.8 & 0.5 \\
\hline 13. & $\left(\mathrm{CH}_{3} \mathrm{O}\right)_{2}(\mathrm{OH})^{28} \mathrm{Si}-\mathrm{O}^{+}$ & $\mathrm{C}_{2} \mathrm{H}_{7} \mathrm{O}_{4}{ }^{28} \mathrm{Si}$ & 5.0 & - & 123.0113 & 123.0284 & $>10$ & 0.5 \\
\hline 14. & $\left(\mathrm{CH}_{3} \mathrm{O}\right)_{3}{ }^{30} \mathrm{Si}^{+}$ & $\mathrm{C}_{3} \mathrm{H}_{9} \mathrm{O}_{3}{ }^{30} \mathrm{Si}$ & 4.5 & 4.2 & 123.0289 & 123.0284 & 0.5 & 0.5 \\
\hline 15. & $\left(\mathrm{CH}_{3} \mathrm{O}\right)_{3}{ }^{29} \mathrm{Si}^{+.}$ & $\mathrm{C}_{3} \mathrm{H}_{9} \mathrm{O}_{3}{ }^{29} \mathrm{Si}$ & 8.3 & 8.6 & 122.0316 & 122.0351 & -3.5 & 0.5 \\
\hline 16. & $\left(\mathrm{CH}_{3} \mathrm{O}\right)_{3}{ }^{28} \mathrm{Si}^{+.}$ & $\mathrm{C}_{3} \mathrm{H}_{9} \mathrm{O}_{3}{ }^{28} \mathrm{Si}$ & 98.8 & $\rightarrow 98.8$ & 121.0321 & 121.0332 & -1.1 & 0.5 \\
\hline 17. & $\left(\mathrm{CH}_{3} \mathrm{O}\right)_{2}(\mathrm{OH})^{30} \mathrm{Si}^{+}$ & $\mathrm{C}_{2} \mathrm{H}_{7} \mathrm{O}_{3}{ }^{30} \mathrm{Si}$ & 1.0 & 0.7 & 109.0132 & 109.0177 & -4.5 & 0.5 \\
\hline 18. & $\left(\mathrm{CH}_{3} \mathrm{O}\right)_{2}(\mathrm{OH})^{29} \mathrm{Si}^{+}$ & $\mathrm{C}_{2} \mathrm{H}_{7} \mathrm{O}_{3}{ }^{29} \mathrm{Si}$ & 1.5 & 1.2 & 108.0160 & 108.0102 & 5.8 & 0.5 \\
\hline 19. & $\left(\mathrm{CH}_{3} \mathrm{O}\right)_{2}(\mathrm{OH})^{28} \mathrm{Si}^{+}$ & $\mathrm{C}_{2} \mathrm{H}_{7} \mathrm{O}_{3}{ }^{28} \mathrm{Si}$ & 16.2 & $\rightarrow \quad 16.2$ & 107.0164 & 107.0192 & -2.8 & 0.5 \\
\hline 20. & $\left(\mathrm{CH}_{3} \mathrm{O}\right)\left(\mathrm{C}_{2} \mathrm{H}_{5} \mathrm{O}\right)(\mathrm{H})^{28} \mathrm{Si}^{+}$ & $\begin{array}{c}\mathrm{C}_{3} \mathrm{H}_{9} \mathrm{O}_{2} \\
{ }^{28} \mathrm{Si}^{+}\end{array}$ & 2.6 & - & 105.0371 & 105.0257 & $>10$ & 0.5 \\
\hline 21. & $\left(\mathrm{CH}_{3} \mathrm{O}\right)_{2}(\mathrm{H})^{30} \mathrm{Si}^{+}$ & $\mathrm{C}_{2} \mathrm{H}_{7} \mathrm{O}_{2}{ }^{30} \mathrm{Si}$ & $2.5+$ & 1.3 & 93.0183 & 93.0130 & 5.3 & 0.5 \\
\hline 22. & $\left(\mathrm{CH}_{3} \mathrm{O}\right)_{2}(\mathrm{H})^{29} \mathrm{Si}^{+}$ & $\mathrm{C}_{2} \mathrm{H}_{7} \mathrm{O}_{2}{ }^{29} \mathrm{Si}$ & 2.7 & 2.4 & 92.0211 & 92.0199 & 1.2 & 0.5 \\
\hline 23. & $\left(\mathrm{CH}_{3} \mathrm{O}\right)_{2}(\mathrm{H})^{28} \mathrm{Si}^{+}$ & $\mathrm{C}_{2} \mathrm{H}_{7} \mathrm{O}_{2}{ }^{28} \mathrm{Si}$ & 32.5 & $\rightarrow 32.5$ & 91.0215 & 91.0213 & 0.2 & 0.5 \\
\hline 24. & $\left(\mathrm{CH}_{3} \mathrm{O}\right)(\mathrm{OH})(\mathrm{H}){ }^{30} \mathrm{Si}^{+}$ & $\mathrm{CH}_{5} \mathrm{O}_{2}{ }^{30} \mathrm{Si}$ & $1.2+$ & 0.6 & 79.0026 & 79.0051 & -2.5 & 0.5 \\
\hline 25. & $\left(\mathrm{CH}_{3} \mathrm{O}\right)(\mathrm{OH})(\mathrm{H}){ }^{29} \mathrm{Si}^{+}$ & $\mathrm{CH}_{5} \mathrm{O}_{2}{ }^{29} \mathrm{Si}$ & 1.1 & 1.0 & 78.0054 & 78.0110 & -4.8 & 0.5 \\
\hline 26. & $\left(\mathrm{CH}_{3} \mathrm{O}\right)(\mathrm{OH})(\mathrm{H}){ }^{28} \mathrm{Si}^{+}$ & $\mathrm{CH}_{5} \mathrm{O}_{2}{ }^{28} \mathrm{Si}$ & 15.8 & $\rightarrow 15.8$ & 77.0058 & 77.0106 & 4.8 & 0.5 \\
\hline 27. & $\left(\mathrm{C}_{2} \mathrm{H}_{5} \mathrm{O}\right)(\mathrm{H})_{2}{ }^{28} \mathrm{Si}^{+}$ & $\mathrm{C}_{2} \mathrm{H}_{7} \mathrm{O}^{28} \mathrm{Si}$ & 4.1 & - & 75.0266 & 75.0153 & $>10$ & 0.5 \\
\hline 28. & $(\mathrm{OH})_{2}(\mathrm{H}){ }^{28} \mathrm{Si}^{+}$ & $\mathrm{H}_{3} \mathrm{O}_{2}{ }^{28} \mathrm{Si}$ & 3.1 & - & 62.9902 & 62.9883 & 1.9 & 0.5 \\
\hline 29. & $\left(\mathrm{CH}_{3} \mathrm{O}\right)(\mathrm{H})_{2}{ }^{28} \mathrm{Si}^{+}$ & $\mathrm{CH}_{5} \mathrm{O}^{28} \mathrm{Si}$ & 6.0 & - & 61.0109 & 61.0131 & -2.2 & 0.5 \\
\hline 30. & $\left(\mathrm{CH}_{3} \mathrm{O}\right){ }^{28} \mathrm{Si}^{+}$ & $\mathrm{CH}_{3} \mathrm{O}^{28} \mathrm{Si}$ & 8.5 & - & 58.9953 & 58.9944 & 0.9 & 0.5 \\
\hline 31. & (H) ${ }^{28} \mathrm{Si}^{+}=\mathrm{O}$ & $\mathrm{HO}^{28} \mathrm{Si}$ & 5.2 & - & 44.9797 & 44.9801 & -0.4 & 1.5 \\
\hline 32. & $(\mathrm{H}) 3{ }^{28} \mathrm{Si}^{+}$ & $\mathrm{H}_{3}{ }^{28} \mathrm{Si}^{+}$ & 1.5 & - & 31.0004 & 31.0080 & -7.6 & 0.5 \\
\hline 33. & $\mathrm{C}_{2} \mathrm{H}_{5}{ }^{+}$ & $\mathrm{C}_{2} \mathrm{H}_{5}$ & 0.9 & - & 29.0391 & 29.0364 & 2.7 & 0.5 \\
\hline 34. & $\mathrm{CH}_{3}{ }^{+}$ & $\mathrm{CH}_{3}$ & 1.1 & - & 15.0234 & 15.0218 & 1.6 & 0.5 \\
\hline
\end{tabular}

Table 12. The $\mathrm{M}+1, \mathrm{M}+2$ isotopic effects, accurate mass measurements at high resolution $\mathrm{R}=5000$ and double bond equivalent (DBE) for the ions of the mass spectrum of tetramethoxysilane (TR4M)

\begin{tabular}{|c|c|c|c|c|c|c|c|c|}
\hline $\begin{array}{l}\text { Crt. } \\
\text { no. }\end{array}$ & Structural formulas & $\begin{array}{c}\text { Ionic } \\
\text { formulas }\end{array}$ & $\mathrm{I}_{\mathrm{EXP}} \%$ & $\mathrm{I}_{\mathrm{CALC}} \%$ & $\begin{array}{c}\text { Calculate } \\
\text { mass }\end{array}$ & $\begin{array}{l}\text { Experimental } \\
\text { mass }\end{array}$ & $\begin{array}{c}\text { Error } \\
(\mathrm{mmu})\end{array}$ & DBE \\
\hline 1. & $\left(\mathrm{CH}_{3} \mathrm{O}\right){ }_{4}{ }^{30} \mathrm{Si}^{+.}$ & $\mathrm{C}_{4} \mathrm{H}_{12} \mathrm{O}_{4}{ }^{30} \mathrm{Si}$ & 0.4 & 0.3 & 154.0473 & 154.0461 & 1.2 & 0 \\
\hline 2. & $\left(\mathrm{CH}_{3} \mathrm{O}\right){ }_{4}{ }^{29} \mathrm{Si}^{+}$. & $\mathrm{C}_{4} \mathrm{H}_{12} \mathrm{O}_{4}{ }^{29} \mathrm{Si}$ & 1.0 & 0.8 & 153.0500 & 153.0610 & $<-10$ & 0 \\
\hline 3. & $\left(\mathrm{CH}_{3} \mathrm{O}\right)_{4}{ }^{28} \mathrm{Si}^{+}$ & $\mathrm{C}_{4} \mathrm{H}_{12} \mathrm{O}_{4}{ }^{28} \mathrm{Si}$ & 76.1 & $\rightarrow 76.1$ & 152.0504 & 152.0522 & -1.7 & 0 \\
\hline 4. & $\left(\mathrm{CH}_{3} \mathrm{O}\right)_{3}{ }^{28} \mathrm{Si}-\mathrm{O}-\mathrm{C}^{+} \mathrm{H}_{2}$ & $\mathrm{C}_{4} \mathrm{H}_{11} \mathrm{O}_{4}{ }^{28} \mathrm{Si}$ & 16.6 & - & 151.0426 & 151.0409 & 1.7 & 0.5 \\
\hline 5. & $\left(\mathrm{CH}_{3} \mathrm{O}\right)_{3}{ }^{28} \mathrm{Si}-\mathrm{O}^{+}$ & $\mathrm{C}_{3} \mathrm{H}_{9} \mathrm{O}_{4}{ }^{28} \mathrm{Si}$ & & - & 137.0269 & 137.0255 & 1.4 & 0.5 \\
\hline 6. & $\left(\mathrm{CH}_{3} \mathrm{O}\right)_{3}{ }^{30} \mathrm{Si}^{+.}$ & $\mathrm{C}_{3} \mathrm{H}_{9} \mathrm{O}_{3}{ }^{30} \mathrm{Si}$ & 1.9 & & 123.0289 & 123.0081 & $>10$ & 0.5 \\
\hline 7. & $\left(\mathrm{CH}_{3} \mathrm{O}\right)_{3}{ }^{29} \mathrm{Si}^{+}$. & $\mathrm{C}_{3} \mathrm{H}_{9} \mathrm{O}_{3}{ }^{29} \mathrm{Si}$ & 0.4 & & 122.0316 & 122.0408 & -9.2 & 0.5 \\
\hline 8. & $\left(\mathrm{CH}_{3} \mathrm{O}\right)_{3}{ }^{28} \mathrm{Si}^{+}$ & $\mathrm{C}_{3} \mathrm{H}_{9} \mathrm{O}_{3}{ }^{28} \mathrm{Si}$ & \multicolumn{2}{|c|}{$6.4 \rightarrow 6.4$} & 121.0321 & 121.0304 & 1.6 & 0.5 \\
\hline 9. & $\left(\mathrm{CH}_{3} \mathrm{O}\right)_{2}(\mathrm{OH})^{30} \mathrm{Si}^{+}$ & $\mathrm{C}_{2} \mathrm{H}_{7} \mathrm{O}_{3}{ }^{30} \mathrm{Si}$ & 5.3 & 4.1 & 109.0132 & 109.0142 & -1.0 & 0.5 \\
\hline 10. & $\left(\mathrm{CH}_{3} \mathrm{O}\right)_{2}(\mathrm{OH})^{29} \mathrm{Si}^{+}$ & $\mathrm{C}_{2} \mathrm{H}_{7} \mathrm{O}_{3}{ }^{29} \mathrm{Si}$ & 8.1 & 7.2 & 108.0159 & 108.0185 & -2.6 & 0.5 \\
\hline 11. & $\left(\mathrm{CH}_{3} \mathrm{O}\right)_{2}(\mathrm{OH})^{28} \mathrm{Si}^{+}$ & $\mathrm{C}_{2} \mathrm{H}_{7} \mathrm{O}_{3}{ }^{28} \mathrm{Si}$ & \multicolumn{2}{|c|}{$100.0 \rightarrow 100.0$} & 107.0164 & 107.0177 & -1.3 & 0.5 \\
\hline 12. & $\left(\mathrm{CH}_{3} \mathrm{O}\right)_{2}(\mathrm{H})^{30} \mathrm{Si}^{+}$ & $\mathrm{C}_{2} \mathrm{H}_{7} \mathrm{O}_{2}{ }^{30} \mathrm{Si}$ & - & & 93.0183 & 93.0045 & $>10$ & 0.5 \\
\hline 13. & $\left(\mathrm{CH}_{3} \mathrm{O}\right)_{2}(\mathrm{H})^{29} \mathrm{Si}^{+}$ & $\mathrm{C}_{2} \mathrm{H}_{7} \mathrm{O}_{2}{ }^{29} \mathrm{Si}$ & - & & 92.0211 & 92.0105 & $>10$ & 0.5 \\
\hline 14. & $\left(\mathrm{CH}_{3} \mathrm{O}\right)_{2}(\mathrm{H})^{28} \mathrm{Si}^{+}$ & $\mathrm{C}_{2} \mathrm{H}_{7} \mathrm{O}_{2}{ }^{28} \mathrm{Si}$ & \multicolumn{2}{|c|}{$2.1 \rightarrow 2.1$} & 91.0214 & 91.0120 & 9.5 & 0.5 \\
\hline 15. & $\left(\mathrm{CH}_{3} \mathrm{O}\right)(\mathrm{OH})(\mathrm{H})^{30} \mathrm{Si}^{+}$ & $\mathrm{CH}_{5} \mathrm{O}_{2}{ }^{30} \mathrm{Si}$ & 1.3 & 1.3 & 79.0027 & 78.9978 & 4.9 & 0.5 \\
\hline 16. & $\left(\mathrm{CH}_{3} \mathrm{O}\right)(\mathrm{OH})(\mathrm{H})^{29} \mathrm{Si}^{+}$ & $\mathrm{CH}_{5} \mathrm{O}_{2}{ }^{29} \mathrm{Si}$ & 2.8 & 2.0 & 78.0054 & 78.0062 & -0.8 & 0.5 \\
\hline 17. & $\left(\mathrm{CH}_{3} \mathrm{O}\right)(\mathrm{OH})(\mathrm{H})^{28} \mathrm{Si}^{+}$ & $\mathrm{CH}_{5} \mathrm{O}_{2}{ }^{28} \mathrm{Si}$ & \multicolumn{2}{|c|}{32.9} & 77.0059 & 77.0098 & -3.9 & 0.5 \\
\hline 18. & $\left(\mathrm{C}_{2} \mathrm{H}_{5} \mathrm{O}\right)(\mathrm{H})_{2}{ }^{28} \mathrm{Si}^{+}$ & $\mathrm{C}_{2} \mathrm{H}_{7} \mathrm{O}^{28} \mathrm{Si}$ & 1.2 & - & 75.0266 & 75.0003 & $>10$ & 0.5 \\
\hline
\end{tabular}




\begin{tabular}{|l|c|c|r|r|r|r|c|c|}
\hline 19. & $(\mathrm{OH})_{2}(\mathrm{H})^{28} \mathrm{Si}^{+}$ & $\mathrm{H}_{3} \mathrm{O}_{2}{ }^{28} \mathrm{Si}$ & 14.9 & - & 62.9902 & 62.9943 & -4.1 & 0.5 \\
\hline 20. & $\left(\mathrm{CH}_{3} \mathrm{O}\right)(\mathrm{H})_{2}{ }^{28} \mathrm{Si}^{+}$ & $\mathrm{CH}_{5} \mathrm{O}^{28} \mathrm{Si}$ & 0.5 & - & 61.0109 & 61.0151 & -4.1 & 0.5 \\
\hline 21. & $\left(\mathrm{CH}_{3} \mathrm{O}\right)^{28} \mathrm{Si}^{+}$ & $\mathrm{CH}_{3} \mathrm{O}^{28} \mathrm{Si}$ & 1.4 & - & 58.9953 & 58.9992 & -3.9 & 0.5 \\
\hline 22. & $\left(\mathrm{H}^{28} \mathrm{Si}^{+}=\mathrm{O}\right.$ & $\mathrm{HO}^{28} \mathrm{Si}$ & 8.4 & - & 44.9797 & 44.9830 & -3.3 & 1.5 \\
\hline 23. & $\left(\mathrm{H}_{3}{ }^{28} \mathrm{Si}^{+}\right.$ & $\mathrm{H}_{3}{ }^{28} \mathrm{Si}^{+}$ & 3.4 & - & 31.0004 & 31.0245 & $<-10$ & 0.5 \\
\hline 24. & $\mathrm{C}_{2} \mathrm{H}_{5}{ }^{+}$ & $\mathrm{C}_{2} \mathrm{H}_{5}$ & 1.2 & - & 29.0391 & 29.0444 & -5.3 & 0.5 \\
\hline 25. & $\mathrm{CH}_{3}{ }^{+}$ & $\mathrm{CH}_{3}$ & 1.9 & - & 15.0235 & 15.0226 & 0.9 & 0.5 \\
\hline
\end{tabular}

3.7. The reaction pathways in the spectrum of dimethoxydiethoxysilane (TR2M) 3.7.1. Primary events. Cleavages of $\sigma$ bonds. The B/E linked scan

$$
\begin{aligned}
& \left.\mathrm{M}-\mathrm{OCH}_{3}\right\rceil^{+} \quad \mathrm{m} / \mathrm{z} 149 \quad \mathrm{I}=4.3 \% \\
& \mathrm{M}^{+\cdot}-\mathrm{CH}_{3} \mathrm{O} \longrightarrow \mathrm{M}-\mathrm{OCH}_{3}^{7+} \\
& \left(\mathrm{CH}_{3} \mathrm{O}\right)\left(\mathrm{C}_{2} \mathrm{H}_{5} \mathrm{O}\right)_{2} \mathrm{~S}^{-}-\underline{0}-\underline{\mathrm{O}}-\mathrm{CH}_{3} \stackrel{-\overline{\mathrm{O}} \mathrm{CH}_{3}}{\longrightarrow}\left(\mathrm{CH}_{3} \mathrm{O}\right)\left(\mathrm{C}_{2} \mathrm{H}_{5} \mathrm{O}\right)_{2} \mathrm{Si}^{+}
\end{aligned}
$$

$$
\begin{array}{lllll}
\mathrm{C}_{5} \mathrm{H}_{13} \mathrm{O}_{3} \mathrm{Si} & \mathrm{M}_{\mathrm{ELE}}=149.0633 & \mathrm{M}_{\mathrm{OBS}}=149.0583 & \Delta \mathrm{M}=5.1 \mathrm{mmu} & \mathrm{DBE}=0,5 \\
\hline
\end{array}
$$

Removal of a $\mathrm{CH}_{3} \mathrm{O}^{\circ}$ radical is a characteristic reaction of the TEOS methoxy-transesters. The arguments of the existence of the ion obtained by the reaction (9) are shown in the gray frame and are extracted from Table 10.

\subsubsection{Elimination of neutral molecules. Elimination of formaldehyde}

$$
\begin{aligned}
& \left.\mathrm{M}-\mathrm{CH}_{3}-\mathrm{CH}_{2} \mathrm{O}\right]^{+} \mathrm{m} / \mathrm{z} \quad 135 \quad \mathrm{I}=64.3 \% \\
& \mathrm{M}-\mathrm{CH}_{3}{ }^{7+}-\mathrm{CH}_{2} \mathrm{O} \longrightarrow \underline{\mathrm{m} / \mathbf{z} 135} \\
& \left(\mathrm{CH}_{3} \mathrm{O}\right)_{2}\left(\mathrm{C}_{2} \mathrm{H}_{5} \mathrm{O}\right) \mathrm{Si}_{\mathrm{m} / \mathrm{z} 165}^{+}+\mathrm{CH}_{2} \stackrel{-\underline{\mathrm{O}}=\mathrm{CH}_{2}}{\longrightarrow} \stackrel{\left(\mathrm{CH}_{3} \mathrm{O}\right)_{2}\left(\mathrm{C}_{2} \mathrm{H}_{5} \mathrm{O}\right) \mathrm{Si}^{+}}{\longrightarrow}
\end{aligned}
$$

\begin{tabular}{lllll}
$\mathrm{C}_{4} \mathrm{H}_{11} \mathrm{O}_{3} \mathrm{Si}$ & $\mathrm{M}_{\mathrm{ELE}}=135.0477$ & $\mathrm{M}$ oBS $=135.0530$ & $\Delta \mathrm{M}=-5.3 \mathrm{mmu}$ & $\mathrm{DBE}=0,5$ \\
\hline
\end{tabular}

The elimination of formaldehyde is typical for methoxy transesters and for alkoxides with methoxy group; for the TR2M molecular species, formaldehyde removal is experimentally demonstrated by the $(\mathrm{B} / \mathrm{E})(1-\mathrm{E})^{1 / 2}$ linked scan; among the fragmentation ions removing $\mathrm{CH}_{2} \mathrm{O}$ is also the ion with $\mathrm{m} / \mathrm{e} 165$ (Figure 7.c) which is confirmed by the exact measurement of its mass and the equivalent of double bonds shown in the grey background and extracted from Table 10.

\subsubsection{Mixed elimination of ethylene and formaldehyde}

$$
\begin{aligned}
& \mathrm{M}-\mathrm{OC}_{2} \mathrm{H}_{5}-\mathrm{C}_{2} \mathrm{H}_{4}{ }^{7+}-\mathrm{CH}_{2} \mathrm{O} \longrightarrow \underline{\mathrm{m} / \mathbf{z} 77} \\
& \left(\mathrm{CH}_{3} \mathrm{O}\right)_{2}(\mathrm{OH}) \mathrm{Si}^{+} \longrightarrow\left(\mathrm{CH}_{3} \mathrm{O}\right)(\mathrm{OH}) \stackrel{+}{\mathrm{Si}_{2} \mathrm{H}} \\
& \mathrm{m} / \mathrm{z} 107 \quad \mathrm{O}-\mathrm{CH}_{2} \\
& \left(\mathrm{CH}_{3} \mathrm{O}\right)(\mathrm{OH})(\mathrm{H}) \mathrm{Si}_{(\mathrm{O} Y}{ }^{+}+\mathrm{CH}_{2} \stackrel{-\overline{\mathrm{O}}=\mathrm{CH}_{2}}{\longrightarrow}\left(\mathrm{CH}_{3} \mathrm{O}\right)(\mathrm{OH})(\mathrm{H}) \mathrm{Si}^{+}
\end{aligned}
$$




\section{$\mathrm{CH}_{5} \mathrm{O}_{2} \mathrm{Si} \quad \mathrm{M}_{\mathrm{ELE}}=77.0058 \quad \mathrm{M}_{\mathrm{OBS}}=77.0140 \quad \Delta \mathrm{M}=-8.2 \mathrm{mmu} \quad \mathrm{DBE}=0,5$}

The first argument for the presence of the ion $\left(\mathrm{CH}_{3} \mathrm{O}\right)(\mathrm{HO})(\mathrm{H}) \mathrm{Si}^{+}$obtained in the reaction (11) is the concordance between the theoretical ionic mass and the experimentally measured one at high resolution $\mathrm{R}=5000$ (Table 10) and presented together with the value of double bond equivalent (DBE) in a grey background.

The second argument is the measurements of the M+1 and M+2 isotopic effects for the discussed ion. In Table 10 for the ion molecular formula, $\mathrm{CH}_{5} \mathrm{O}_{2} \mathrm{Si}$ we have a mass spectrum intensity of $19.4 \%$ and the experimental $\mathrm{M}+1$ and $\mathrm{M}+2$ isotopic effects have the values 1.5 and 0.8 where the main contribution is of the ${ }^{29} \mathrm{Si}$ and ${ }^{30} \mathrm{Si}$ isotopes of silicon. These values are consistent with the values calculated theoretically by the ISO dedicated program [18] of $1.2 \%$ and $0.7 \%$, respectively.

The significant reaction pathways explaining the mass spectrum of the TR2M molecular specie are given in Table 13 according to data in Tables 3, 10, Figures 2.c, 4, 5.b, 6.a, 7.c.

Table 13. Mass spectrum of dimethoxydiethoxysilane. Fragmentation pathways. Accurate masses

\begin{tabular}{|lll|}
\hline$\left(\mathrm{CH}_{3} \mathrm{O}\right)_{2}\left(\mathrm{C}_{2} \mathrm{H}_{5} \mathrm{O}\right)_{2} \mathrm{Si}$ & $\mathrm{C}_{6} \mathrm{H}_{16} \mathrm{O}_{4} \mathrm{Si}$ & $\mathrm{M}=180$ \\
\hline
\end{tabular}

I. The ionization process

\begin{tabular}{|c|c|c|}
\hline $\mathrm{M}-\mathrm{e} \rightarrow \mathrm{M}^{+}$ & $180-\mathrm{e} \rightarrow 180^{+}$ & Int $=8.9 \%$ \\
\hline
\end{tabular}

II. Fragmentation reactions

\begin{tabular}{|c|c|c|c|c|}
\hline \multicolumn{4}{|c|}{ Primary events. Cleavage of $\sigma$ bonds } & Int $\%$ \\
\hline A.1. & $\mathrm{M}-\mathrm{H}^{+}$ & $\rightarrow 179.0783^{+}$ & $\leftarrow 180-1^{7+}$ & 4.8 \\
\hline A.2. & $\mathrm{M}-\mathrm{CH}_{3}{ }^{7+}$ & $\rightarrow 165.0554^{+}$ & $\leftarrow 180-15^{{ }^{\dagger+}}$ & 100.0 \\
\hline A.3. & $\mathrm{M}-\mathrm{C}_{2} \mathrm{H}_{5}{ }^{1+}$ & $\rightarrow 151.0483^{+}$ & $\leftarrow \quad 180-29^{7+}$ & 16.1 \\
\hline A. 4 . & $\mathrm{M}-\mathrm{OCH}_{3}{ }^{7+}$ & $\rightarrow 149.0583^{+}$ & $\leftarrow 180-31^{{ }^{\top}+}$ & 4.3 \\
\hline A.5. & $\mathrm{M}-\mathrm{OC}_{2} \mathrm{H}_{5}{ }^{7+}$ & $\rightarrow 135.0530^{+}$ & $\leftarrow 180-45^{7+}$ & 64.3 \\
\hline A.6. & $\mathrm{M}-2 \mathrm{OCH}_{3}{ }^{+}$ & $\rightarrow 118^{+}$ & $\leftarrow 180-62^{7+}$ & 0.2 \\
\hline A.7. & $\mathrm{M}-\mathrm{OCH}_{3}-\mathrm{OC}_{2} \mathrm{H}_{5}{ }^{7+}$ & $\rightarrow 104$ & $\leftarrow 180-76^{7+}$ & 2.7 \\
\hline
\end{tabular}

B. Eliminations of neutral molecules

\begin{tabular}{|c|c|c|c|c|c|}
\hline \multicolumn{2}{|c|}{$\begin{array}{l}\text { B.1. Eliminations of acetaldehyde } \\
\qquad \mathrm{CH}_{3} \mathrm{CHO} \quad \mathrm{M}=44\end{array}$} & Int. \% & \multicolumn{2}{|c|}{$\begin{array}{l}\text { B.2. Eliminations of ethylene } \\
\mathrm{CH}_{2}=\mathrm{CH}_{2} \quad \mathrm{M}=28\end{array}$} & Int. \% \\
\hline B.1.1. & $179^{+}-44 \longrightarrow 135.0530^{+}$ & 64.3 & B.2.1. & $179^{+}-28 \longrightarrow 151.0483^{+}$ & 16.1 \\
\hline 2. & $165^{+}-44 \longrightarrow 121.0377^{+}$ & 46.6 & 2. & $163^{+}-28 \longrightarrow 135.0530^{+}$ & 64.3 \\
\hline 3. & $151^{+}-44 \longrightarrow 107.0244^{+}$ & 37.1 & 3. & $149^{+}-28 \longrightarrow 121.0377^{+}$ & 46.6 \\
\hline 4. & $149^{+}-44 \longrightarrow 105.0392^{+}$ & 11.2 & 4. & $135^{+}-28 \longrightarrow 107.0244^{+}$ & 37.1 \\
\hline 5. & $135^{+}-44 \longrightarrow 91.0243^{+}$ & 25.7 & 5. & $121^{+}-28 \longrightarrow 93.0059^{+}$ & 10.2 \\
\hline & & & 6. & $105^{+}-28 \longrightarrow 77.0140^{+}$ & 33.0 \\
\hline
\end{tabular}

\begin{tabular}{|c|c|c|}
\hline \multicolumn{2}{|c|}{ B.3. Eliminations of formaldehyde } & Int \% \\
\hline $\mathrm{CH}_{2} \mathrm{O} \quad \mathrm{M}=30$ & \\
\hline B.3. 1. & $179^{+}-30 \longrightarrow 149.0583^{+}$ & 4.3 \\
\hline 2. & $165^{+}-30 \longrightarrow 135.0530^{+}$ & 64.3 \\
\hline 3. & $151^{+}-30 \longrightarrow 121.0377^{+}$ & 46.6 \\
\hline
\end{tabular}




\begin{tabular}{|c|c|c|}
\hline 4. & $135^{+}-30 \longrightarrow 105.0392^{+}$ & 11.2 \\
\hline 5. & $121^{+}-30 \longrightarrow 91.0249^{+}$ & 25.7 \\
\hline 6. & $107^{+}-30 \longrightarrow 77.0140^{+}$ & 33.0 \\
\hline 7. & $93^{+}-30 \longrightarrow 62.9918^{+}$ & 15.0 \\
\hline
\end{tabular}

\section{Conclusions}

The author's procedure for the interpretation of mass spectra of silicon alkoxides $[1,13]$ was applied in the present work for methoxytriethoxysilane (TR1M), dimethoxydiethoxysilane (TR2M), trimethoxyethoxysilane (TR3M) and tetramethoxysilane (TR4M, TMOS).

The ions of the mass spectra of the TEOS methoxy-transesters were obtained experimentally by the $\mathrm{B} / \mathrm{E}$ and $\mathrm{B} / \mathrm{E}(1-\mathrm{E})^{1 / 2}$ linked scans

The argument for the existence of two possible reaction sites for the oxygen atom of the methoxy group or the ethoxy group was obtained by calculating the net atomic charges with the MOPAC program 7.

The primary fragmentation reactions and the neutral molecule eliminations (formaldehyde, acetaldehyde, ethylene, molecular hydrogen) were written based on information obtained experimentally by the $\mathrm{B} / \mathrm{E}$ and $\mathrm{B} / \mathrm{E}(1-\mathrm{E})^{1 / 2}$ linked scans.

The elimination of two methoxy groups simultaneously occurs for the TEOS methoxy-transesters with 2-4 methoxy groups. An example is the ion of m/e 90 in the mass spectrum of tetramethoxysilane (TMOS). This ion can be obtained by ionization of two oxygen atoms by the simultaneous elimination of two methoxy groups from the molecular ion.

35 ions were obtained for TR1M, 35 ions for TR2M, 34 ions for TR3M and 25 ions for TR4M (TMOS). Tetramethoxysilane (TMOS) was considered the second reference system along with tetraethoxysilane (TEOS).

The strong argument for the existence of TEOS methoxy-transesters ions was based on accurate masses measurements at high resolution $(\mathrm{R}=5000)$. It is found that for virtually all ions in the spectra of these molecular species we have differences less than 10 mili mass unit ( $\mathrm{mmu}$ ) between the observed and calculated masses.

An argument in favor of the existence of an ion in the mass spectrum is the $\mathrm{M}+1, \mathrm{M}+2$ isotopic effects, where the main contribution is of the ${ }^{29} \mathrm{Si}$ and ${ }^{30} \mathrm{Si}$ isotopes of silicon. A good concordance between the experimental values of the M+1, M+2 isotopic effects and those calculated with the ISO dedicated program is found.

The reaction pathways in the mass spectrum of dimethoxydiethoxysilane (TR2M) and accurate mass values are presented in detail.

\section{References}

1. BADESCU, V., Ph. D. Thesis, Romanian Academy, Bucharest, Inst. Phys. Chem., 1998.

2. WHEELER, G. E., Ph. D. Thesis, New York University, 1987.

3. BADESCU, V. RADU, M., ZAHARESCU M., VASILESCU, A., J. Sol-Gel Sci. Tech. 2, 1994, p. 43-49.

4. ZAHARESCU, M., VASILESCU, A., BADESCU V. and RADU, M., J. Sol-Gel Sci. Tech., 8, 1997, p. 59-63.

5. JITIANU, A., BRITCHI, A., DELEANU, C., BADESCU V., ZAHARESCU, M., J. Non-Cryst. Solids, 319, 2003, p. 263-279.

6. ZAHARESCU, M., BADESCU, V., VASILESCU A., JITIANU, A., "Emerging Fields in Sol-Gel Science and Technology", Kluwer Academic Publishers, 2003, p.157-164.

7. BADESCU, V.,ZAHARESCU, M., VASILESCU A., RADU, M., Rev. Roum. Chim., 41,1996, p. 733-740. 
8. ZAHARESCU, M., BADESCU, V., VASILESCU A., RADU, M., Rev. Roum. Chim., 42,1997, p. 633-639.

9. JITIANU, A., BRITSCHI, A., BADESCU, V., DELEANU, C., ZAHARESCU, M., Rev. Roum. Chim., 52, 2007, p. 93-99.

10. I. OPREAN, I., "Mass spectrometry of organic compounds", Editura Dacia, Cluj,1974.

11. McLAFFERTY, F. W., "Interpretation of Mass Spectra”, 4th edition, Benjamin, Reading, 1993.

12. BUDZIKIEWICZ, H., DJERASSI, C. and WILLIAMS, D. H., "Mass Spectrometry of Organic Compounds", Holden Day, San Francisco,1967, p.86.

13. BADESCU, V., Rev. Roum. Chim., 59(10), 2014, p. 875-882.

14. BADESCU, V., Rev. Roum. Chim., 60 (11-12), 2015, p. 1107-1115.

15. BADESCU, V., Rev. Chim., 70(8). 2019, 2934.

16. BADESCU, V., Rev. Chim., 71(5), 2020, in press.

17. BADESCU, V., Proceedings MDPI, Volume 29, PRIOCHEM XV, 2019, p. 181-184.

18. Mass Spectral Libraries, V2.1, Isotope Calculator Soft Program, NIST 2005, Perkin Elmer, Inc. 2006.

Manuscripr received: 13.04 .2020 